Dredging Operations and Environmental Research Program

Dredging Effects on Eelgrass

(Zostera marina) Distribution in a New England Small Boat Harbor

Bruce Sabol, Deborah Shafer, and Elizabeth Lord July 2005

US Army Corps of Engineers ${ }_{\circledast}$

Engineer Research and Development Center 


\section{Dredging Effects on Eelgrass (Zostera marina) Distribution in a New England Small Boat Harbor}

Bruce Sabol, Deborah Shafer, and Elizabeth Lord

Environmental Laboratory

U.S. Army Engineer Research and Development Center

3909 Halls Ferry Road

Vicksburg, MS 39180-6199

Final report

Approved for public release; distribution is unlimited 


\begin{abstract}
While speculation on effects of dredging on seagrass beds is plentiful, actual empirical data documenting these effects are not. In this study, acoustic-based seagrass mapping techniques were used to generate detailed maps of seagrass distribution before and after dredging operations. Eelgrass (Zostera marina) within Scituate Harbor, MA, was monitored during mid-summer in 2001, 2003, and 2004; navigation maintenance dredging of the harbor was performed during fall 2002. Similar surveys were also performed during the same timeframe at an undredged harbor near Wood Island, ME. Two types of potential impacts were examined. Direct impacts involved physical removal of vegetation along with the dredged sediments. Indirect impacts in adjacent undredged areas may occur as a result of increased turbidity and/or siltation associated with dredging activities. Using hydroacoustic techniques, the authors were able to easily map and quantify direct impacts to eelgrass resources. Assessment of indirect impacts, however, was more complex. In the first post-dredging survey, a substantial reduction in coverage occurred in adjoining undredged areas, suggesting possible indirect impacts. This was followed by a modest recovery between the first and second post-dredging years. However, monitoring of other undredged sites within the region showed natural year-to-year variations in eelgrass coverage to be almost as large as those occurring at the dredged site. Results emphasize the need for long-term data to discern any potential effects of dredging on seagrass dynamics as opposed to a host of other factors contributing to high variability in measured parameters.
\end{abstract}

DISCLAIMER: The contents of this report are not to be used for advertising, publication, or promotional purposes. Citation of trade names does not constitute an official endorsement or approval of the use of such commercial products. All product names and trademarks cited are the property of their respective owners. The findings of this report are not to be construed as an official Department of the Army position unless so designated by other authorized documents. 


\section{Contents}

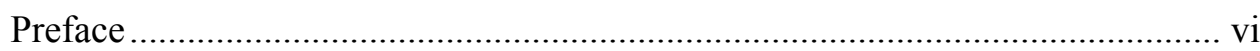

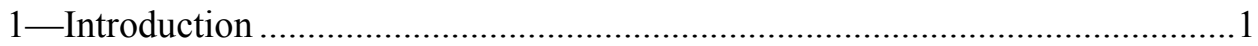

2 - Site Descriptions and Dredging Activity .......................................................

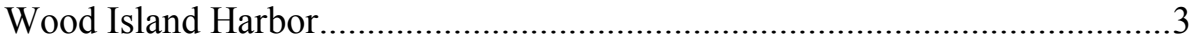

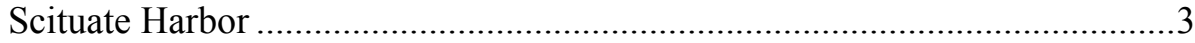

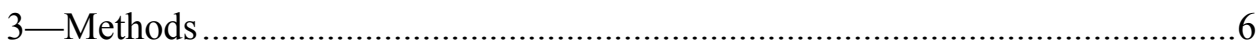

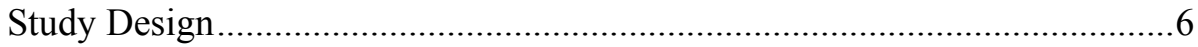

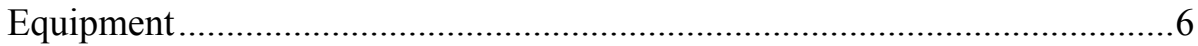

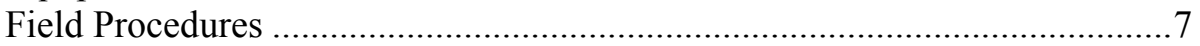

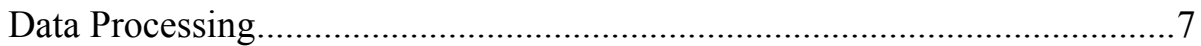

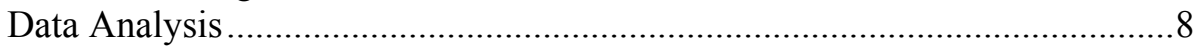

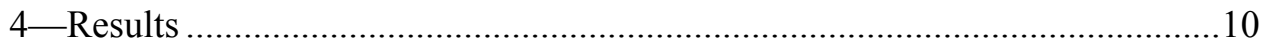

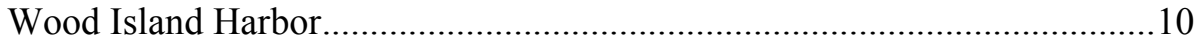

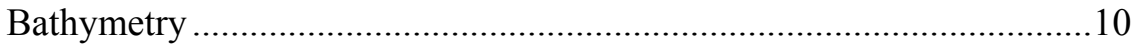

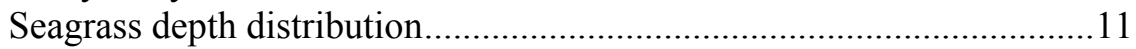

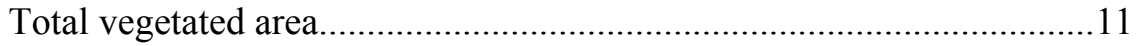

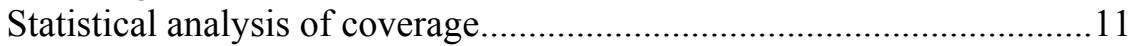

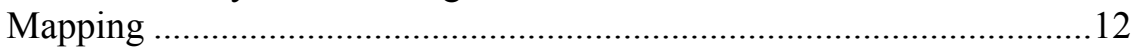

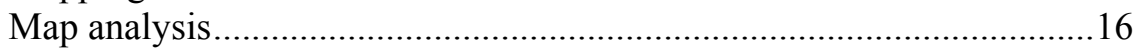

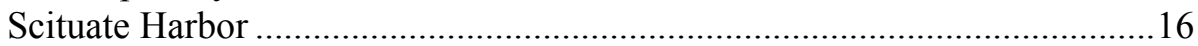

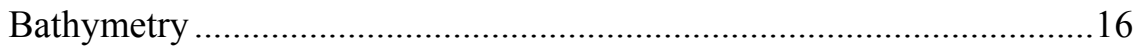

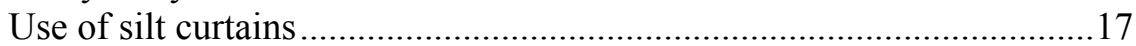

Seagrass depth distribution............................................................... 18

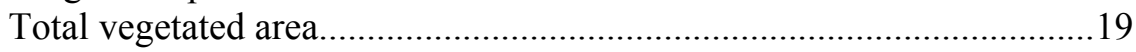

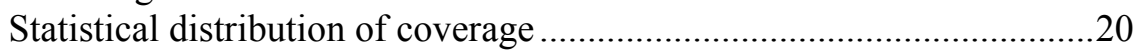

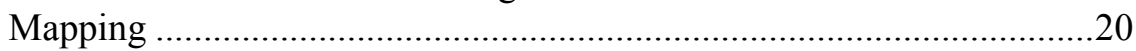

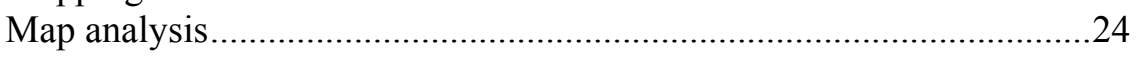

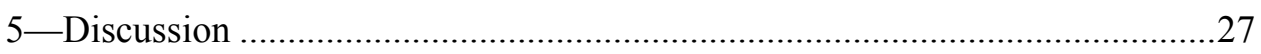

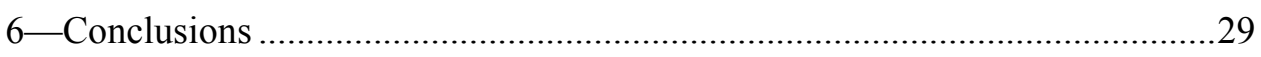

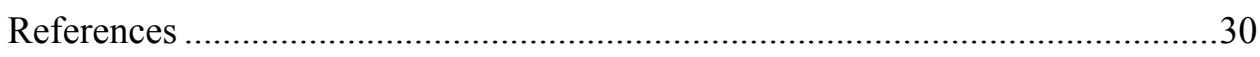

SF 298 


\section{List of Figures}

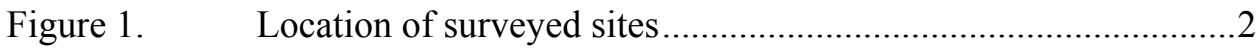

Figure 2. Detailed map of Wood Island Harbor .........................................4

Figure 3. Detailed map of Scituate Harbor; surveyed area and silt curtains indicated........................................................................

Figure 4. Bathymetric maps of Wood Island Harbor, 2003 .......................10

Figure 5. Mean eelgrass coverage by $0.15-\mathrm{m}$ depth increment for Wood Island Harbor ......................................................................11

Figure 6. Distribution of gridded eelgrass coverage for Wood Island Harbor by year.

Figure 7. Eelgrass coverage map of Wood Island Harbor: a) 2001, b) 2003 , c) 2004

Figure 8. Map of eelgrass coverage grid difference for years 2001 and 2003 for Wood Island Harbor.

Figure 9. Map of eelgrass coverage grid difference for years 2003 and 2004 for Wood Island Harbor. 15

Figure 10. Bathymetric map of Scituate Harbor, 2001

Figure 11. Bathymetric grid difference between 2001 and 2003 (pre- and post-dredging): note that negative numbers indicate increased depth while positive numbers indicate decreased depth

Figure 12. Mean eelgrass coverage by $0.15-\mathrm{m}$ depth increment in Scituate Harbor for dredged and undredged anchorage area, and for dredged and undredged channel area

Figure 13. Distribution of gridded eelgrass coverage in Scituate by region......

Figure 14. Eelgrass coverage map of Scituate Harbor: a) 2001, b) 2003, c) 2004 .

Figure 15. Map of eelgrass coverage grid difference for years 2001 and 2003 for Scituate Harbor .

Figure 16. Map of eelgrass coverage grid difference for years 2003 and 2004 for Scituate Harbor .. 


\section{List of Tables}

Table 1. Cover Classes by Year for Wood Island Harbor (computed from Figure 7) ....................................................... 13

Table 2. Eelgrass Coverage Change Analysis for Wood Island

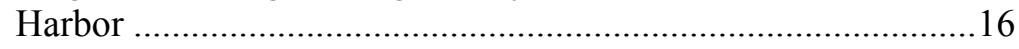

Table 3. Summary of Total Vegetated Area (ha) in Scituate Harbor by Location, Treatment, and Year ................................20

Table 4. Classes of Gridded Eelgrass Coverage Data by Location, Treatment, and Year.

Table 5. Eelgrass Coverage Change Analysis for Dredged Portions of Scituate Harbor . .25

Table 6. Eelgrass Coverage Change Analysis for Undredged Areas of Scituate Harbor . .25

Table 7. Summary of Net and Relative Change in SAV Coverage for Scituate Harbor by Location, Treatment, and Paired Surveys 


\section{Preface}

The U.S. Army Engineer Research and Development Center (ERDC), Environmental Laboratory (EL), has responsibility under the Environmental Resource Protection (ERP) Focus Area of the Dredging Operations and Environmental Research (DOER) Program to identify and evaluate habitats potentially affected by dredging and disposal operations. The DOER ERP focus area partnered with the U.S. Army Engineer District, New England (NAE), to evaluate impacts of dredging on eelgrass established within an NAE small boat harbor subject to dredging.

The ERDC field participants in the study included Bruce Sabol, Deborah Shafer, Kevin Reine, Chuck Dickerson, and Tommy Berry. Mr. Paul O'Brien, captain of the NAE Corps vessel Popham Beach, and his crew provided boat support to this effort. Field coordination and support for the effort were provided by Mr. Steve Johnston, chief of the Survey Branch for the New England District. This report was prepared by Bruce Sabol, Deborah Shafer, and Elizabeth Lord of ERDC. Dr. Douglas Clarke, Environmental Resource Protection Focus Area Manager for DOER, provided technical support in the preparation of this report. Funding for this research was provided by the DOER Program, and by the U.S. Army Engineer District, New England.

This study was performed under the general supervision of Dr. Edwin Theriot, Director, EL, and Dr. Robert Engler, Technical Director of Civil Works R\&D and manager of the DOER Program.

COL James Rowan, EN, was Commander and Executive Director of ERDC. Dr. James R. Houston was Director. 


\section{Introduction}

Seagrasses play an important ecological role in nearshore coastal ecosystems (Thayer et al. 1984, Zieman and Zieman 1989). The dominant seagrass species in the North Atlantic region, eelgrass (Zostera marina), is known to provide food and shelter for a diverse array of fishes and invertebrates (Thayer et al. 1984, Hughes et al. 2002). Many of these species reach their maximum abundance and biomass in areas of high eelgrass complexity (Hughes et al. 2002). Eelgrass seeds, roots, and rhizomes can be an important source of food for over-wintering waterfowl (Baldwin and Lovvorn 1994, Ganter 2000). Seagrasses also baffle wave and current energy, increase sediment deposition, and stabilize bottom sediments, thereby improving water quality (Fonseca et al. 1982). Seagrass resources worldwide have been declining, due to a host of factors, both natural and anthropogenic, which could lead to changes in nearshore ecosystem structure and function (Short and Wyllie-Echeverria 1996).

The amount of light, or photosynthetically active radiation (PAR), is a primary limiting factor in the photosynthesis, growth, and depth distribution of seagrasses (Bulthuis 1983, Dennison 1987, Abal et al. 1994, Kenworthy and Fonseca 1996). During dredging and dredged material disposal operations, a certain amount of sediment is resuspended in the water column. Turbidity changes induced by dredging, either on a short-term (during dredging) or longterm basis (due to altered bathymetry or circulation), can conceptually be linked to increased light attenuation in the water column. Consequently, concerns have been raised regarding the potential impacts of dredging activities on seagrass resources (Onuf 1994, Short and Wyllie-Echeverria 1996). Detecting the specific impacts of dredging against a background of natural spatial and temporal variability is challenging, however, and in many cases the impacts of dredging on seagrass resources have not been clearly established (e.g., Quammen and Onuf 1993, Long et al. 1996).

This report describes interannual patterns of eelgrass (Z. marina) distribution at two small boat harbors in New England; Scituate Harbor, Massachusetts, and Wood Island Harbor, Maine. The objectives of this study are to: 1) evaluate potential impacts and recovery of seagrass resources resulting from Federal navigation dredging activities; and 2) estimate the range of natural variability in eelgrass distribution and cover in an undredged harbor. Scituate Harbor was dredged during fall 2002 through winter 2003. Wood Island, Maine, has not been dredged since 1992 and is extensively colonized by eelgrass. Locations of the two sites are shown in Figure 1. 


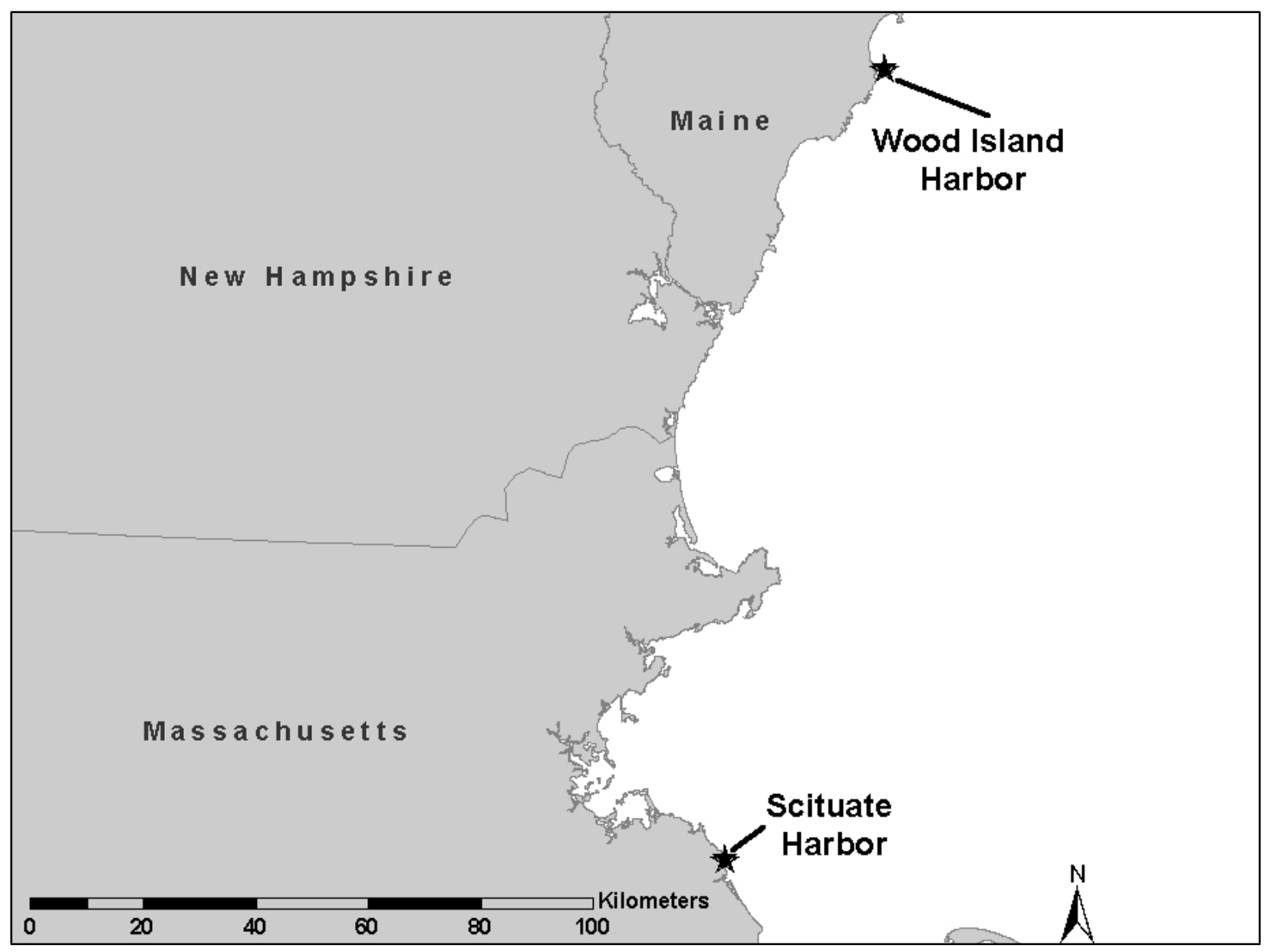

Figure 1. Location of surveyed sites 


\section{Site Descriptions and Dredging Activity}

\section{Wood Island Harbor}

Wood Island Harbor is located on the southern coast of Maine near the mouth of the Saco River (Figure 1). The project consists of a 3.0-m-deep outer channel leading to a 1.8-m-deep anchorage basin within Biddeford Pool (Figure 2). For this study, a 5.25-ha area in the outer channel, containing dense established eelgrass beds, was surveyed. The harbor is used for both commercial and recreational vessels. The mean tidal range is approximately $2.75 \mathrm{~m}$. Dredging was last performed in October 1992. Biological surveys have documented a diverse faunal community in the area (Reynolds and Casterlin 1985).

\section{Scituate Harbor}

Scituate Harbor lies on the southern shore of Massachusetts Bay about $29 \mathrm{~km}$ north of Plymouth Harbor and $37 \mathrm{~km}$ southeast of Boston. The harbor is bounded on the east and north by the Atlantic Ocean and has a tidal shoreline of about $10 \mathrm{~km}$. The mean tidal range is approximately $2.75 \mathrm{~m}$. The harbor is used by both commercial and recreational vessels. The project consists of a $3.7-\mathrm{m}$-deep ${ }^{1}$ entrance channel, a 3.0-m-deep and a 2.4-m-deep outer harbor anchorage basin, a $3.0-\mathrm{m}$ channel in the inner harbor area leading to a 3.0-m-deep inner harbor anchorage basin, and two rubblemound breakwaters (Figure 3).

The harbor was last dredged in 1960 , when $69,000 \mathrm{~m}^{3}$ of sediment were removed from the harbor (High et al. 2001). Appreciable siltation had occurred since then, primarily in the outer harbor anchorage basin. Materials that required dredging included fine sediments (silt) in the anchorage and a limited amount of very coarse sand and cobble in the entrance channel. Dredging was performed from September 2, 2002 to February 10, 2003, using a bucket dredge. Approximately $199,000 \mathrm{~m}^{3}$ of sediment were removed, placed on a barge, and transported to the Massachusetts Bay Disposal site, $24 \mathrm{~km}$ northeast of the harbor, where it was placed in an open-water disposal area.

\footnotetext{
${ }^{1}$ All depths are referenced to mean lower low water (MLLW).
} 


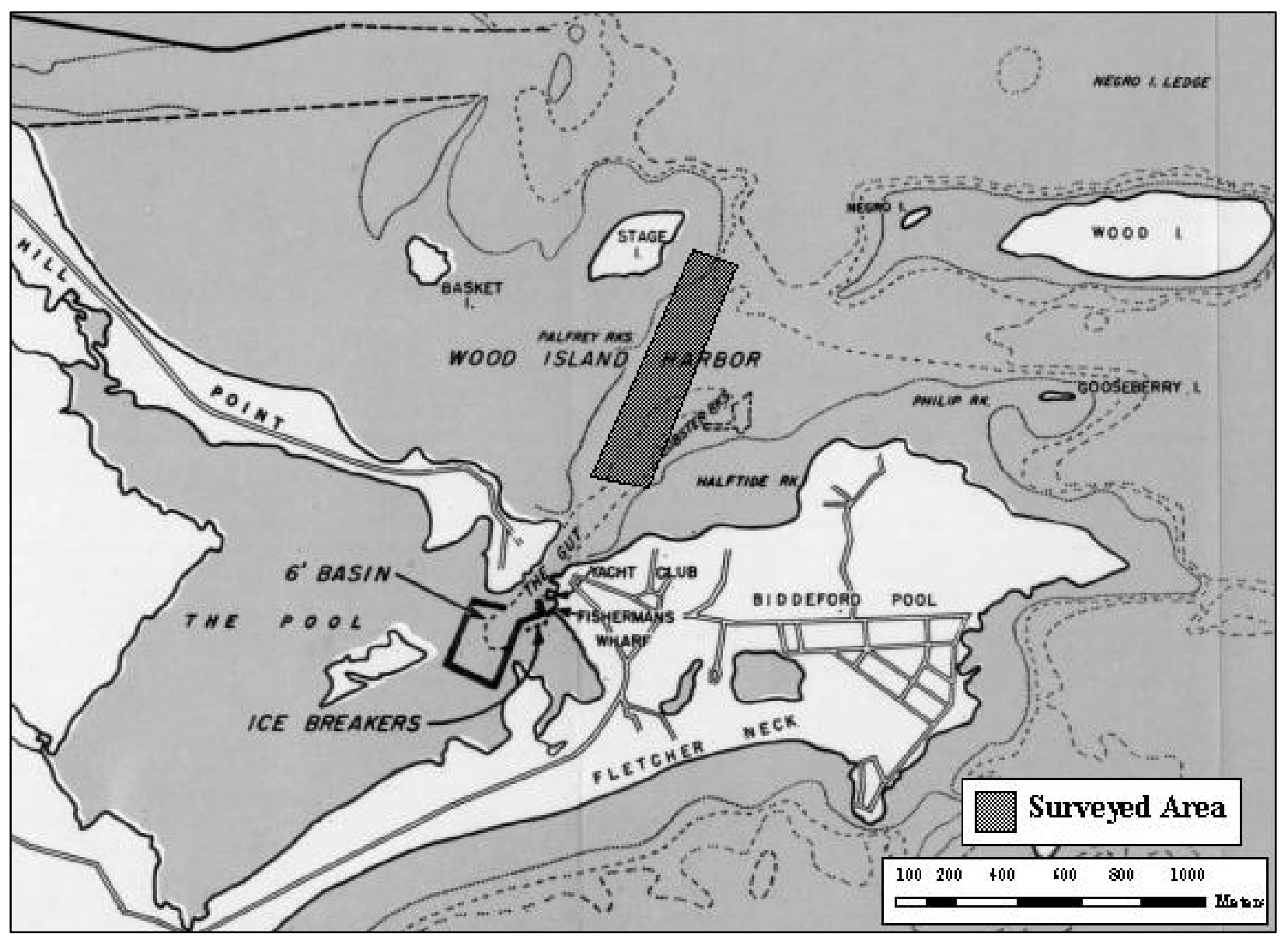

Figure 2. Detailed map of Wood Island Harbor

Coordination with resource agencies prior to dredging led to agreements on specific dredging practices to be used in order to minimize eelgrass impacts in the vicinity of the harbor (High et al. 2001). First, a 15-m-wide lane on the northeast side of the 3.0-m-deep anchorage was not dredged due to dense eelgrass in the immediate vicinity. Second, silt curtains were deployed at three locations where dense eelgrass beds adjoined areas to be dredged within the federal channel (Figure 3). The silt curtains were intended to reduce dredginginduced turbidity and siltation impacts on eelgrass beds.

For the purposes of this study, the surveyed area of the Scituate Harbor was divided into two sections, entrance channel and anchorage, based on differences in sediment type, bottom slope, and current regime. The area surveyed within the entrance channel area was 3.7 ha in size and was characterized by coarse-grained sediments, steep bottom slopes, and relatively high current velocities. The area surveyed in the anchorage area was 10.9 ha in size and was characterized by relatively flat bottom slopes, fine-grained sediments, and relatively slow current velocities. 


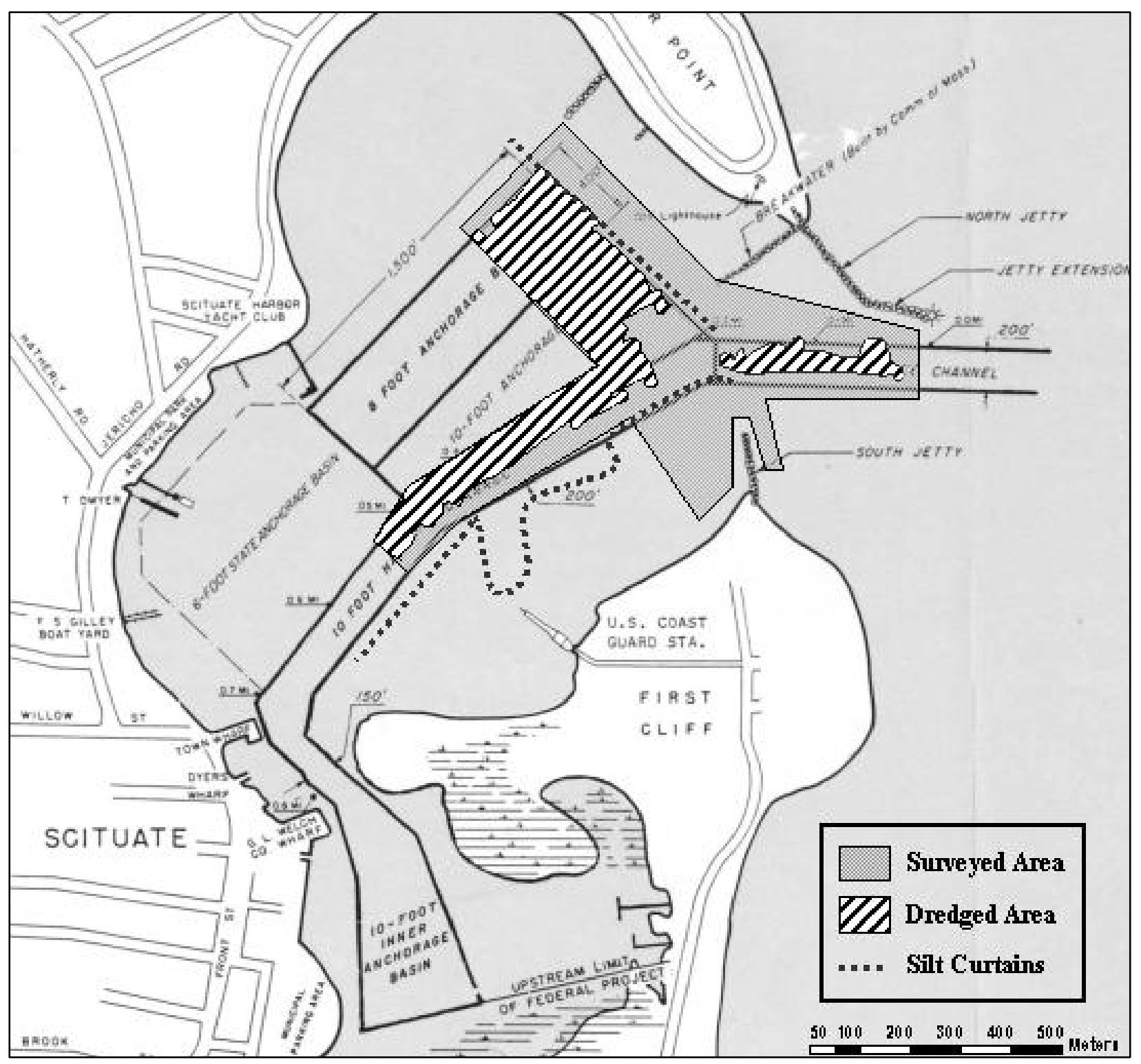

Figure 3. Detailed map of Scituate Harbor; surveyed area and silt curtains indicated 


\section{Methods}

\section{Study Design}

Hydro-acoustic surveys to detect seagrass were performed at each harbor during the month of July in 2001, 2003, and 2004. In Scituate Harbor, the 2001 survey represents pre-dredging conditions, and surveys in 2003 and 2004 represent first year (5 months after) and second year (17 months after) postdredging conditions, respectively. For the purposes of this study, two types of potential dredging impacts were investigated. First, direct impacts, defined as the physical removal of existing vegetation by dredging operations, were examined within dredged areas. Assuming essentially all seagrass in the dredged areas was physically removed as a consequence of dredging operations, the presence of seagrass in the dredged areas in the post-dredging surveys was interpreted as evidence of recovery. Second, indirect impacts to seagrasses in areas adjacent to the dredged areas, but not physically disturbed by the dredging equipment, may occur due to temporary increases in water column light attenuation or sedimentation effects related to dredging operations. The potential for indirect impacts in Scituate Harbor was explored by comparison of interannual patterns of eelgrass distribution within undredged areas.

Similar surveys were performed at Wood Island Harbor, Maine, during the same timeframe. Although both harbors are dominated by $Z$. marina, they are separated by approximately $145 \mathrm{~km}$ (Figure 1). Therefore, eelgrass conditions at Wood Island Harbor are not considered to be an experimental control for eelgrass at Scituate Harbor. Rather, data from Wood Island Harbor are used as an indicator of natural interannual variability of eelgrass within the region. The natural range of interannual variability is seldom considered in seagrass studies, but can be significant (Nelson 1997).

\section{Equipment}

The Submersed Aquatic Vegetation Early Warning System (SAVEWS), developed at the U.S. Army Engineer Research and Development Center (ERDC), was used for all surveys. SAVEWS hardware consists of a digital echosounder, a global positioning system (GPS), and a laptop computer. The hydroacoustic component is a Biosonics DT-series digital echosounder (Biosonics, Inc., Seattle WA) with a 420-kHz, 6-degree single-beam transducer that generates monotone pulses at a rate of $10 \mathrm{~Hz}$, and a $0.1-\mathrm{ms}$ duration. Return 
echoes are digitized at high frequency and dynamic range (22 bits) to generate a return envelope that is sampled at $41.67 \mathrm{kHz}$, corresponding to a depth increment of approximately $1.8 \mathrm{~cm}$. Data are stored on the hard drive of the computer that operates the system. Interspersed with these digitized echo signals are NMEAformat position reports (latitude and longitude, NAD83) recorded at $1 \mathrm{~Hz}$ from the real-time differentially corrected GPS (DGPS), using U.S. Coast Guard broadcast corrections. A Trimble NT 300D GPS system was used, which has a horizontal root mean squared error of approximately $1.5 \mathrm{~m}$. The SAVEWS transducer and co-located GPS antenna were mounted on the bow of the USACE survey vessel Popham Beach. Further details on the SAVEWS hardware can be found in Sabol et al. (2002).

\section{Field Procedures}

Data were collected along established New England District Corps of Engineers survey transects used for precise bathymetry surveys. Survey transects were run parallel to the longitudinal axis of the channel or anchorage at a separation interval of $7.6 \mathrm{~m}$. The survey vessel navigated these transects using its resident DGPS at an average speed of $2.5 \mathrm{~m} \mathrm{sec}^{-1}$. The actual path surveyed was typically within $0.5 \mathrm{~m}$ of the intended transect line except when it was necessary to deviate to avoid a moored boat or other obstacle. During the operations, a member of the survey crew stationed at the local tide gauge radio-transmitted tide reports for every $0.03-\mathrm{m}$ change. These data were used to correct detected bottom depths during post-processing.

\section{Data Processing}

The SAVEWS processor examines the signal strength and spatial distribution of echo signals to determine the bottom depth and detect bottom-attached vegetation. SAVEWS outputs include bottom depth, SAV coverage (percentage of pings within a localized region in which SAV was detected) and mean SAV canopy height (average height of detected plants within the localized region). Under typical operating conditions SAVEWS can detect vegetation exceeding $0.09 \mathrm{~m}$ in height and $60 \mathrm{~g} \mathrm{~m}^{-2}$ (wet weight) biomass. Details of the processing algorithm are described in Sabol et al. (2002). The emphasis of this study was identifying locations containing eelgrass. During the 2001 survey, rake sampling revealed that locations in which the apparent SAV height (based on echosounder screen display) exceeded $0.3 \mathrm{~m}$ contained at least some eelgrass. Locations with an apparent SAV height less than $0.3 \mathrm{~m}$ typically contained only Fucus, a brown marine macroalgae. The SAVEWS processor only measures canopy geometry and currently does not have the ability to discriminate between species. Accordingly, the general height difference between eelgrass and Fucus was used as a discriminating feature. The plant detection threshold was set to $0.3 \mathrm{~m}$, so that only pings with a detected vegetation height of $0.3 \mathrm{~m}$ or more were declared to contain eelgrass. While this discrimination rule appeared to work in July, during peak eelgrass biomass and height, it may not be appropriate at other times of the year. These SAVEWS processing parameters were held constant for all sites and surveys. 
Following initial SAVEWS processing, several types of data manipulation were performed. Manual editing was performed to remove spurious detections resulting from mooring lines and lobster traps, recorded in the field notes. Position data were converted from latitude/longitude in NAD83 to the local state plane coordinates (feet). Massachusetts Mainland (zone 2001, NAD27) was used for Scituate Harbor and Maine West (zone 1802, NAD27) was used for Wood Island Harbor. SAVEWS-detected bottom depths were corrected to MLLW by adjusting for tidal amplitude and transducer depth.

\section{Data Analysis}

A variety of spatial and statistical analyses were employed to evaluate changes in eelgrass distributions. Emphasis was placed on eelgrass coverage and not on canopy height. In areas of strong tidal flow the detected canopy height of tall eelgrass can vary considerably over the course of a tidal cycle (Sabol et al. 1997). Bathymetry was analyzed as a precursor to determine the spatial footprint of dredging. Analysis procedures used are described below.

a. Bathymetric analysis. A linear triangulated irregular network (TIN) interpolation surface was generated using all output depth points. Depth was gridded from this surface at a 3-m spacing. TIN interpolation is the preferred technique for generating bathymetric information from point data related to $\mathrm{CE}$ harbor surveys and dredging (Corps of Engineers 2002). Bathymetric maps were produced for each site and year. Depth grids were differenced between 2001 and 2003, and between 2003 and 2004. For Scituate Harbor the 2001/2003 differencing revealed actual dredged locations, which were used to partition the areas surveyed into dredged and undredged treatment regions. The 2003/2004 differencing for Scituate Harbor reveals differences between first and second year post dredging.

b. Seagrass depth distribution. Because depth is extremely important in determining seagrass distribution, it is informative to compute and plot mean seagrass coverage as a function of depth. The shape of the mean coverage vs. depth curve is characteristic of a site and aids in comparing sites with differing depth distributions. Eelgrass coverage (using ungridded SAVEWS output data) is averaged within $0.15-\mathrm{m}$ depth increments and is graphically illustrated for each site and survey. This analysis is performed by location and treatment effect groups for Scituate Harbor.

c. Gridding coverage data. A natural neighbor interpolation procedure was used to generate a surface using all output coverage points. Eelgrass coverage was gridded at a 3-m spacing using ESRI ARC/Map for each site and survey. Natural neighbor interpolation (Sibson 1981) uses only immediate neighboring points in the interpolation process and is well-suited for highly patchy spatial distributions such as seagrasses. Gridding serves to generate a set of uniformly spaced points exactly matched between successive surveys at a given site. All subsequent analysis and mapping use these gridded data. 
d. Computing total vegetated area. The gridded coverage data were used to compute total vegetated area for each site, survey, and effects factor. All gridded coverage data ranging between 0 and 5 percent were considered unvegetated since 10 percent coverage is the lowest detectable coverage using SAVEWS operated at 10 pings/sec.

e. Statistical distribution of coverage. The statistical distribution of these coverage data was portrayed graphically and converted to equivalent tables of coarse eelgrass coverage classes. This serves to define variations in coverage within vegetated areas, which is not apparent from measures of vegetated area alone.

f. Map generation. Eelgrass coverage maps, classed to the nearest 10 percent, were generated for each site and survey. These graphics facilitate direct visual comparisons between surveys and regions within surveys at each harbor. Next, gridded coverages were spatially compared for pre- and postdredging periods (2001 versus 2003), and for the post-dredging periods (2003 versus 2004). Six mutually exclusive classes of coverage change were delineated and graphically portrayed:

(1) Eelgrass appeared - Eelgrass detected at this location in the later survey but not detected in the previous survey.

(2) Eelgrass increased - Eelgrass detected at this location during both surveys, but exhibited greater coverage (more than 10 percent difference) during the later survey.

(3) Eelgrass unchanged - Eelgrass detected at this location in nearly equal amounts (less than 10 percent difference) during both surveys.

(4) Eelgrass decreased - Eelgrass detected at this location during both surveys, but exhibited greater coverage (more than 10 percent difference) during the earlier survey.

(5) Eelgrass disappeared - Eelgrass not detected at this location in the later survey but detected in the earlier survey.

(6) Unvegetated - no eelgrass detected at this location during either survey.

g. Map analysis. The area and relative portion of area within each of these change categories were computed for each survey comparison pair by counting the number of $3-\mathrm{m}$ by $3-\mathrm{m}$ grid cells. The proportion of area within each of these categories was computed for the two survey comparison pairs by counting the 3-m by 3-m grid cells. For Scituate Harbor, the surveyed area was divided into regions representing the four combinations of location (anchorage versus channel) and treatment (dredged versus undredged) effects. Tables generated in this manner contain a wealth of information but can be somewhat difficult to interpret. To simplify interpretation, increasing coverage classes (sum of eelgrass appeared and eelgrass increased) and decreasing coverage classes (sum of eelgrass decreased and eelgrass disappeared) were subtracted to calculate net change. These data are presented as total area and percentage of total area. 


\section{Results}

\section{Wood Island Harbor}

\section{Bathymetry}

Bathymetric conditions were virtually identical for all three surveys, exhibiting no apparent change from year to year. Accordingly, only the 2003 survey is illustrated (Figure 4). Along the longitudinal axis of the channel, depths ranged from more than $4.25 \mathrm{~m}$ at the ends to less than $3.0 \mathrm{~m}$ near the middle.

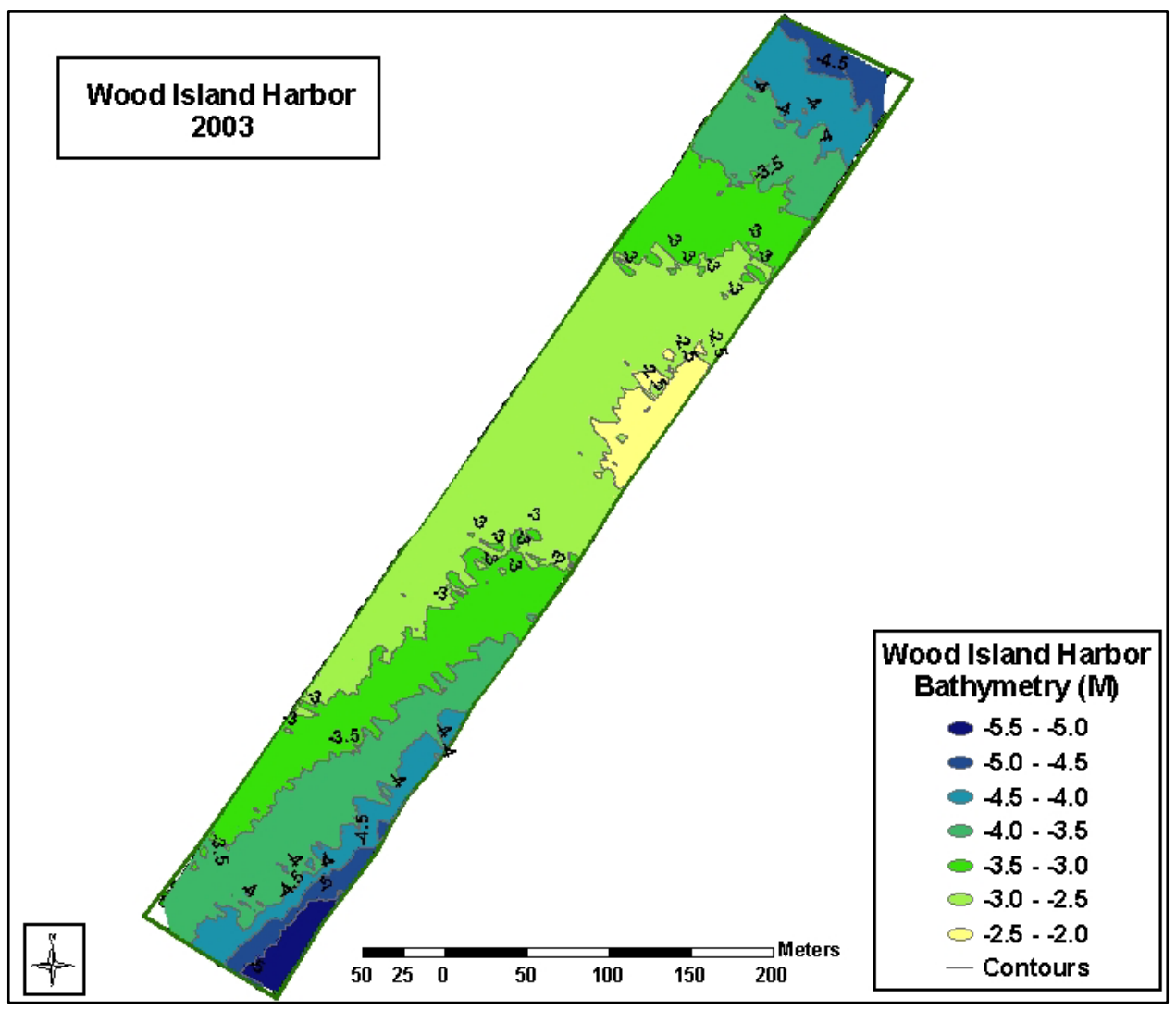

Figure 4. Bathymetric maps of Wood Island Harbor, 2003 


\section{Seagrass depth distribution}

Shifts in the depth distribution of eelgrass coverage between the three surveys were observed (Figure 5). A peak in eelgrass coverage between the 3and 4-m depths, originally seen in 2001, progressively decreased in 2003 and 2004. Also, the middle channel shallows (more than $-2.75 \mathrm{~m}$ ), which were largely unvegetated in 2001 and 2003, showed sparse but extensive eelgrass colonization in 2004.

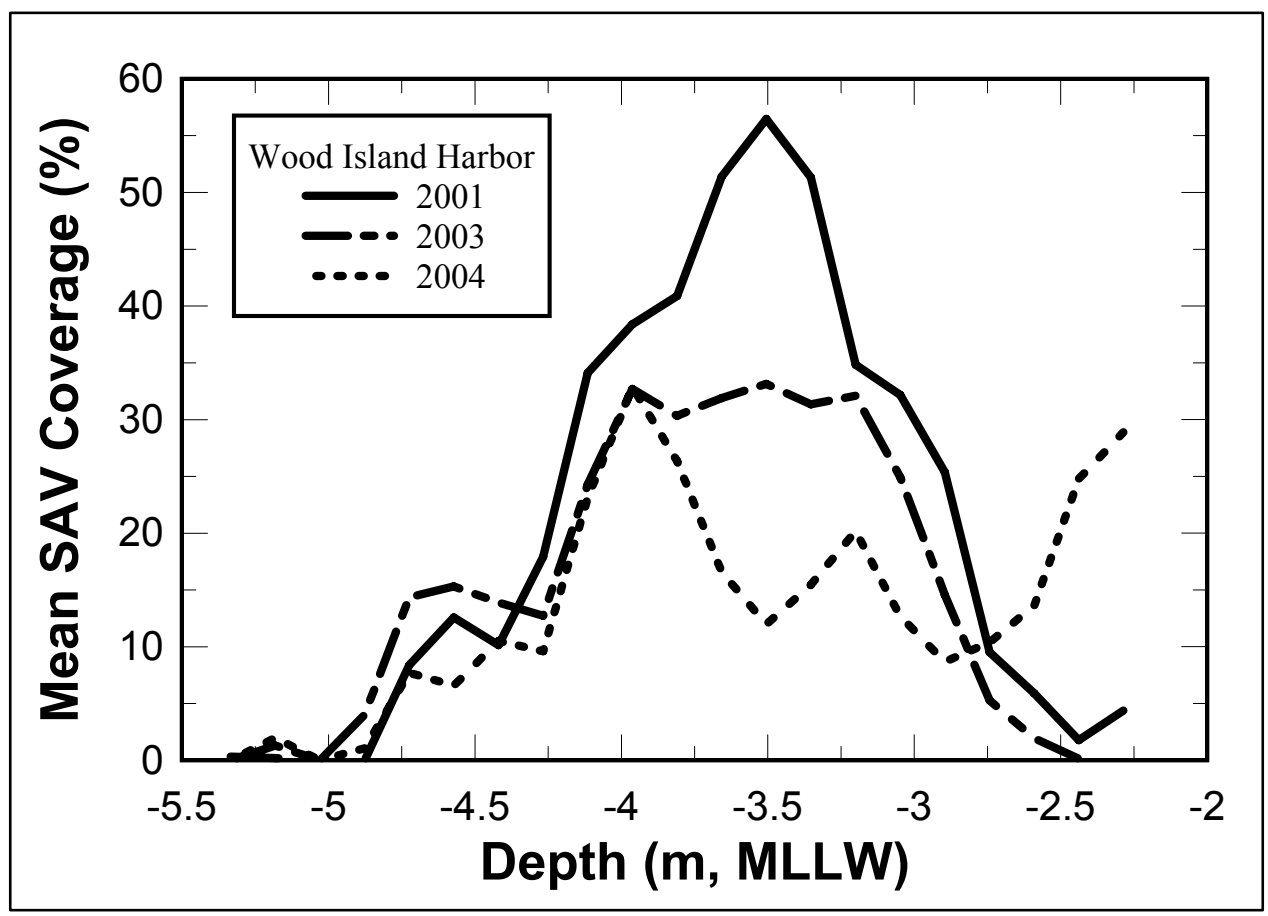

Figure 5. Mean eelgrass coverage by $0.15-\mathrm{m}$ depth increment for Wood Island Harbor

\section{Total vegetated area}

Total vegetated area was 3.24 ha, 2.83 ha, and 2.87 ha for the three sequential surveys, respectively, out of a total surveyed area of $5.25 \mathrm{ha}$. This represents a relative decrease of 13 percent between 2001 and 2003, and a relative increase of 1.4 percent between 2003 and 2004.

\section{Statistical analysis of coverage}

The statistical distribution of gridded coverage values (Figure 6, Table 1) showed a progressive decline of coverage over time. While changes in overall total vegetated area were minor, dense coverage classes appeared to be progressively decreasing in conjunction with simultaneous increases in sparse and moderate coverage classes (Table 1). 


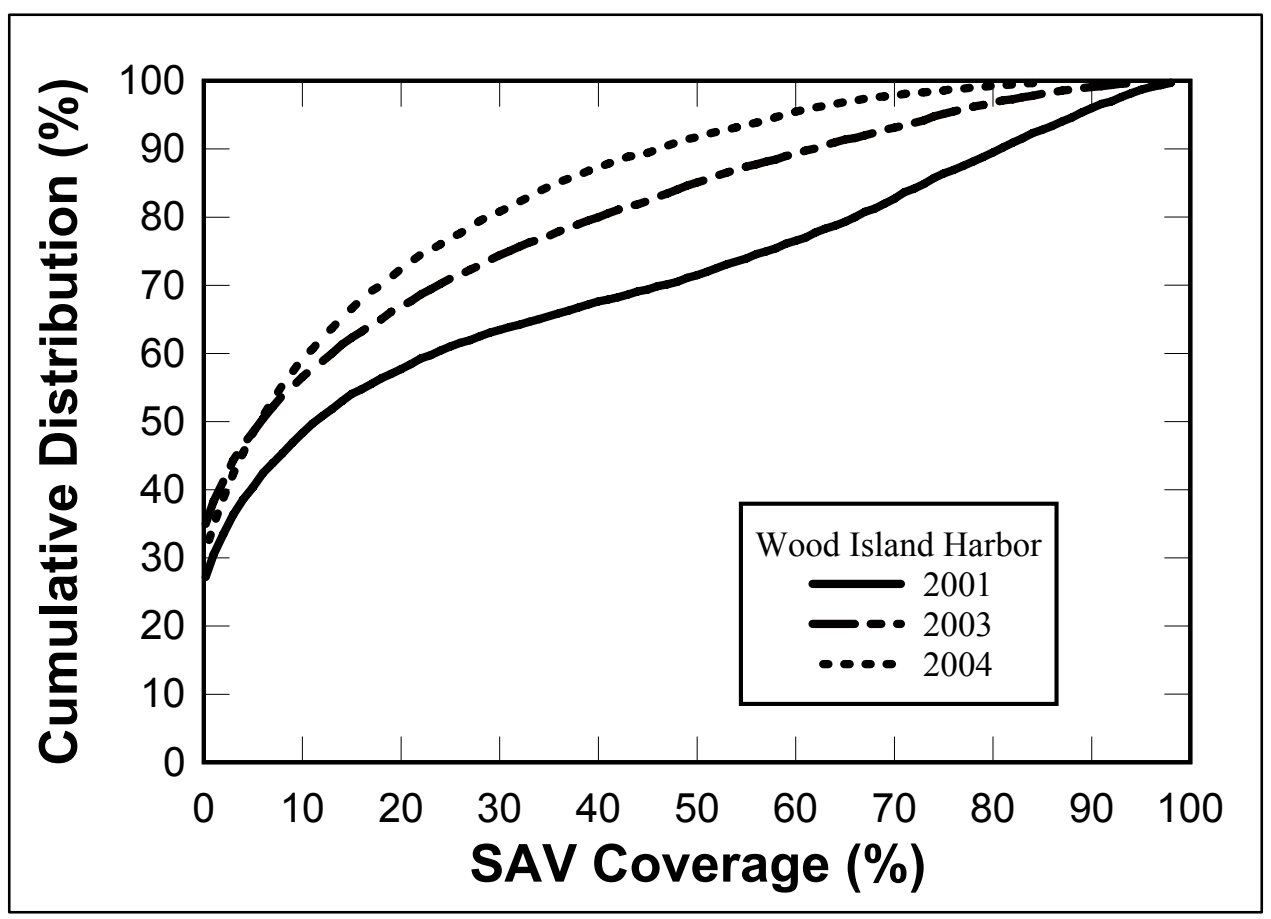

Figure 6. Distribution of gridded eelgrass coverage for Wood Island Harbor by year

\section{Mapping}

Maps of SAV coverage (Figure 7) illustrate how SAV coverage is spatially distributed. The first survey (2001) detected dense eelgrass coverage at the south end of the surveyed area, intermediate coverage at the north end, and little to no coverage in the shallow middle portion. Eelgrass coverage in the 2003 survey reflected an apparent decline in coverage within all established beds. The 2004 survey indicated further decline of beds at the north and south ends, and an appearance of sparse coverage in the shallow middle portion of the channel, where eelgrass had not previously been detected. The differences in gridded eelgrass coverage further illustrate these changes. The 2001/2003 grid difference (Figure 8) exhibits decreased coverage in the southern part of the area with considerable eelgrass disappearance in the northern part of the survey area. The 2003/2004 eelgrass grid difference (Figure 9) shows continued decrease or disappearance in the north and south areas accompanied by a large area of "appearance" in the middle of the surveyed area. 


\begin{tabular}{|c|c|c|c|c|}
\hline $\begin{array}{l}\text { Table } 1 \\
\text { Cover Cle } \\
\text { Figure } 7 \text { ) }\end{array}$ & Year for Woc & d & . & from \\
\hline & & Perc & $\begin{array}{l}\text { ff Grid } \\
\text { (area) }\end{array}$ & erage Points \\
\hline Cover Class & Class Range & 2001 & 2003 & 2004 \\
\hline Unvegetated & $\leq 5$ percent cover & 38.4 & 46.2 & 445.4 \\
\hline Sparse & $>5-25$ percent cover & 22.7 & 24.9 & 31.6 \\
\hline Moderate & $>25-50$ percent cover & 10.5 & 14.1 & 14.8 \\
\hline Dense & $>50-75$ percent cover & 14.9 & 10.1 & 7.8 \\
\hline Very dense & $>75-100$ percent cover & 13.5 & 4.7 & 0.4 \\
\hline
\end{tabular}

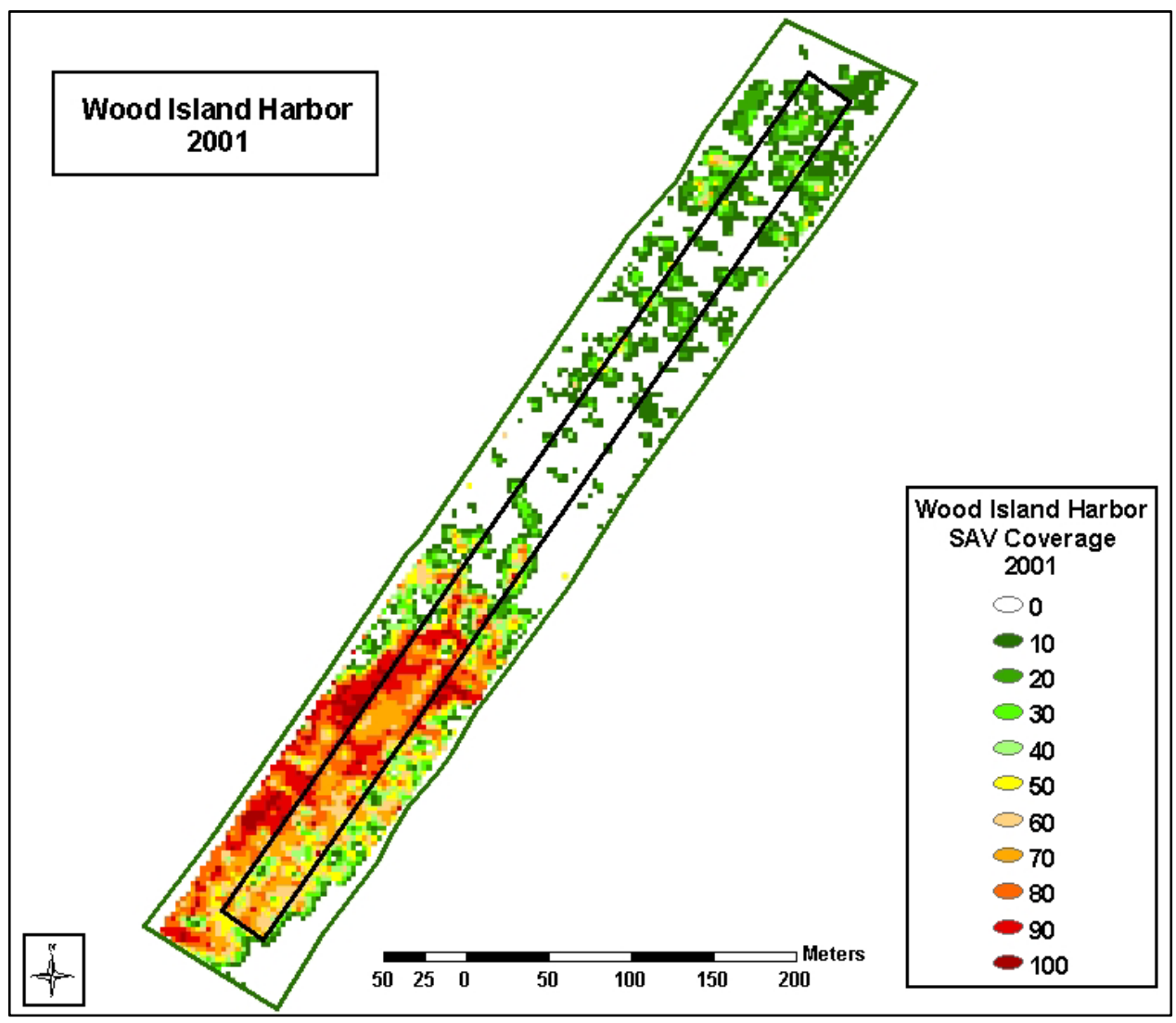

a) 2001

Figure 7. Eelgrass coverage map of Wood Island Harbor: a) 2001, b) 2003, c) 2004 


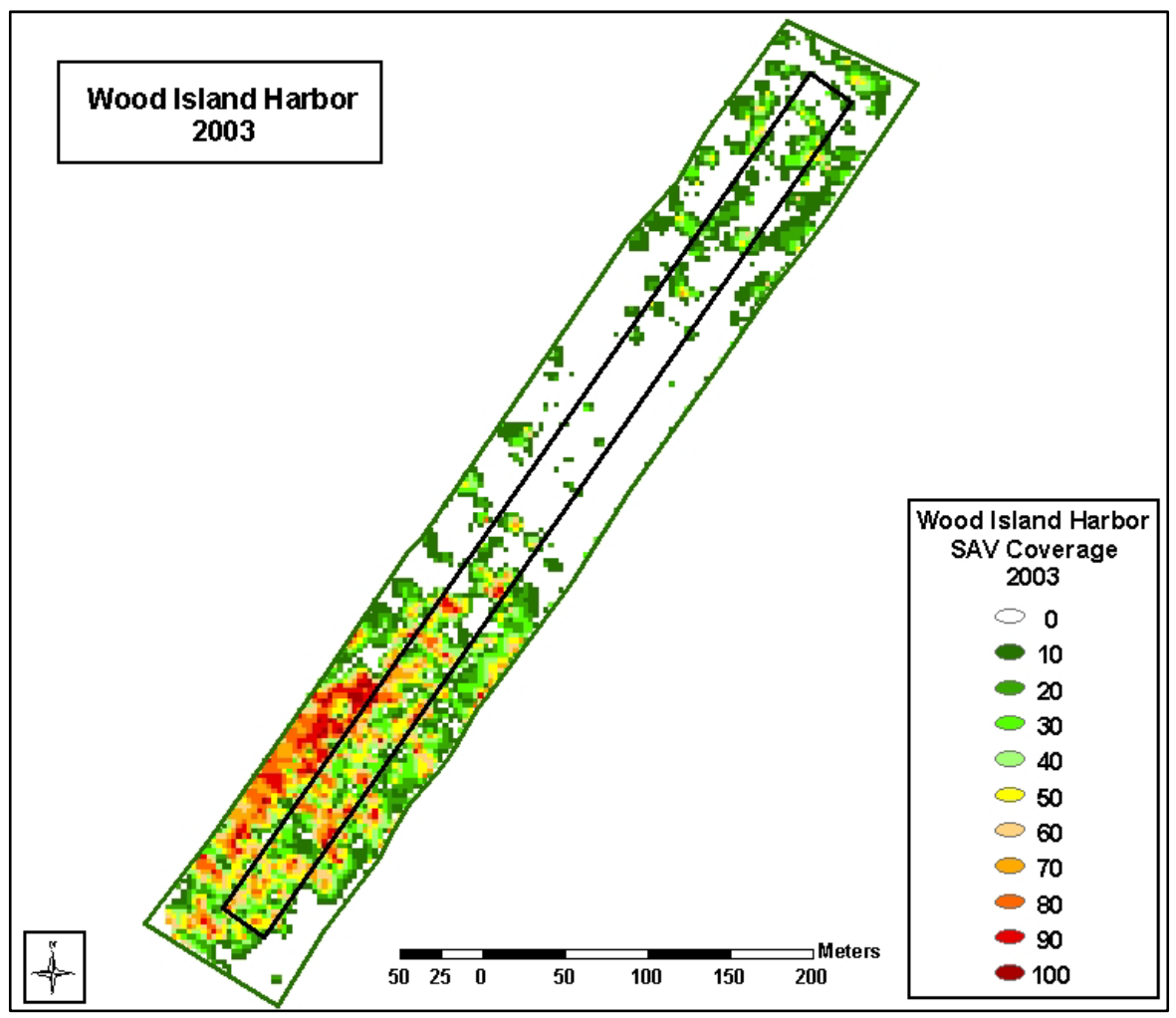

b) 2003

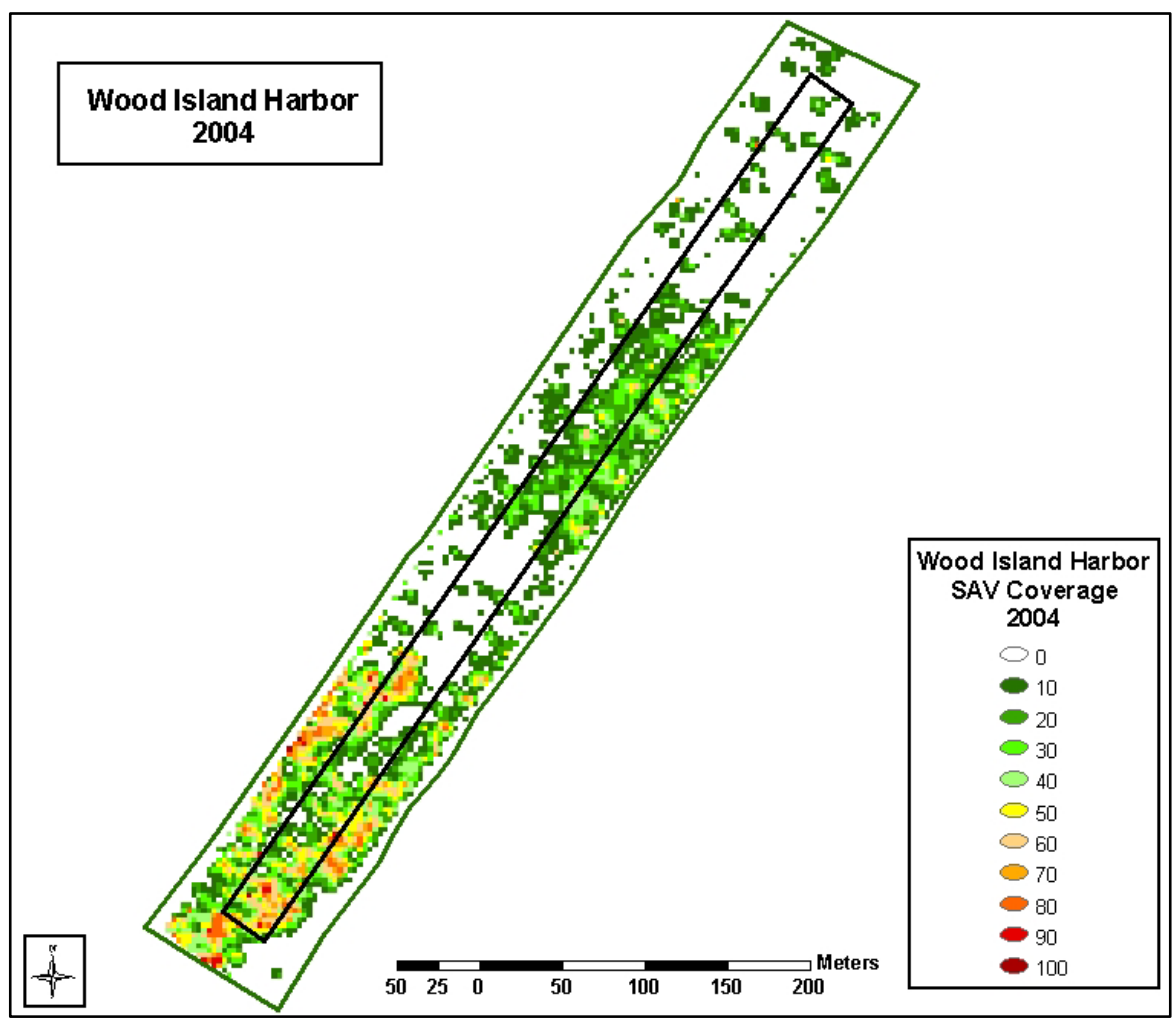

c) 2004 


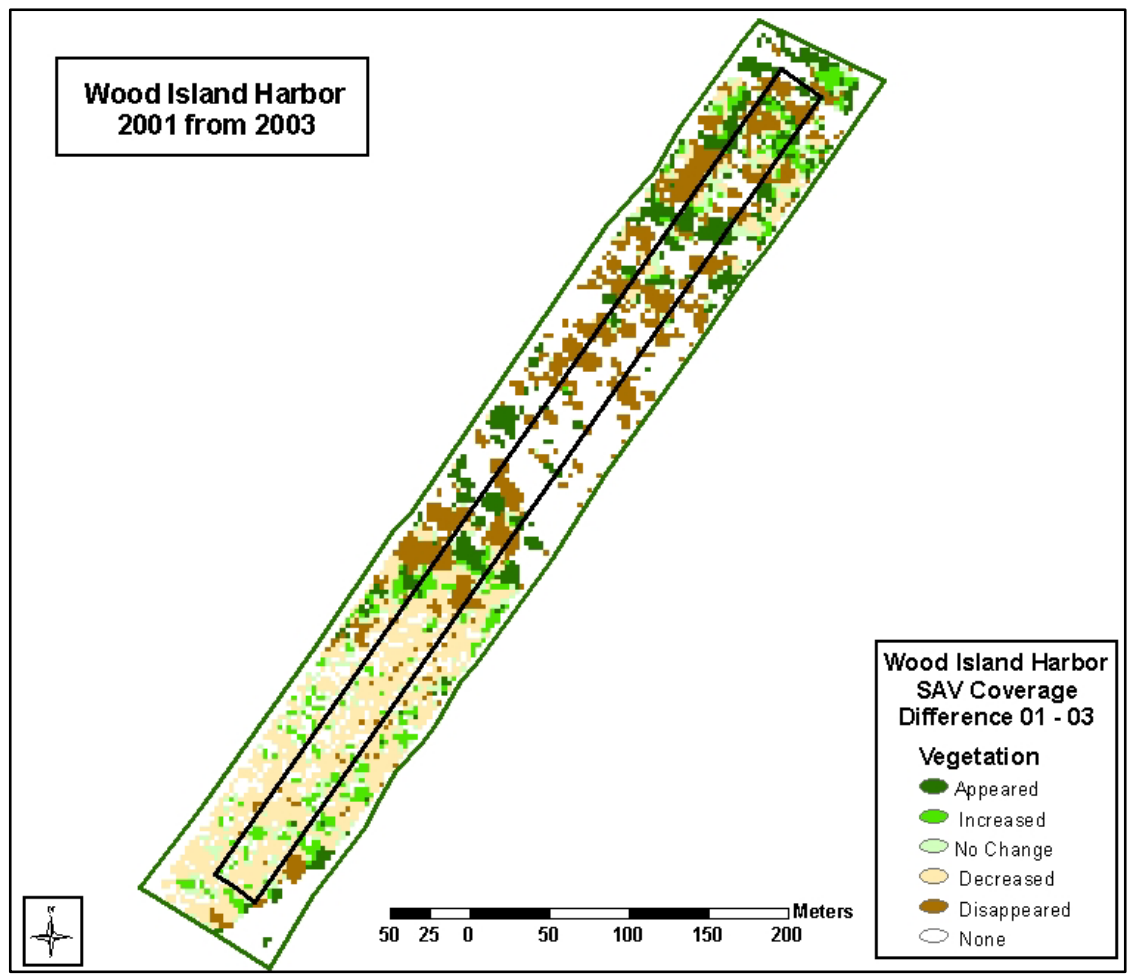

Figure 8. Map of eelgrass coverage grid difference for years 2001 and 2003 for Wood Island Harbor

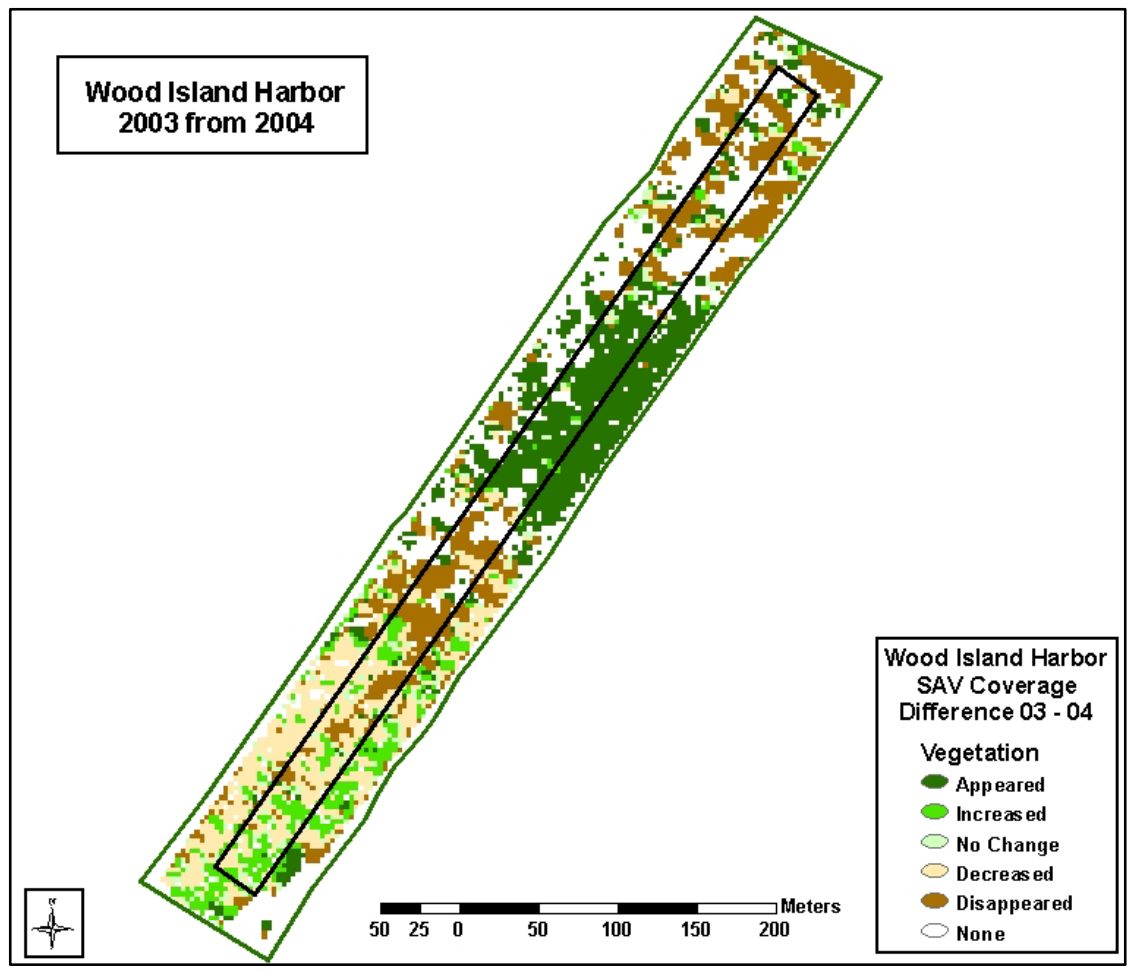

Figure 9. Map of eelgrass coverage grid difference for years 2003 and 2004 for Wood Island Harbor 


\section{Map analysis}

Changes in eelgrass coverage are quantified in Table 2. Between 2001 and 2003 , roughly 20 percent of the total area was classified as increasing coverage ((appeared + increased)/total) and 45 percent of the total area was classified as declining coverage $(($ decreased + disappeared $) /$ total $))$. This represents a net decrease of 25 percent (1.33 ha) of total area, or a relative decrease of 40 percent (1.33ha/3.24ha) of the original 2001 vegetated area. Note that these percentages are larger than those for total vegetated area, described above, because these also account for the areas of increase and decline, not just presence. Between 2003 and 2004, the increasing coverage classes represented 31 percent of the total area while decreasing coverage classes accounted for 39 percent of the total area. This resulted in a net decrease of 8 percent $(0.4 \mathrm{ha}$ ) of the total area, or a relative decline of 15 percent in the vegetated area present in 2003. This indicates that the rate of decline in eelgrass coverage is slowing with time, as was also indicated in Figure 6 and Table 1.

\begin{tabular}{|c|c|c|c|c|}
\hline \multicolumn{5}{|c|}{$\begin{array}{l}\text { Table } 2 \\
\text { Eelgrass Coverage Change Analysis for Wood Island Harbor }\end{array}$} \\
\hline \multirow[b]{2}{*}{ Vegetation Change Category } & \multicolumn{2}{|c|}{$2001 / 2003$} & \multicolumn{2}{|c|}{$2003 / 2004$} \\
\hline & Hectares & $\%$ Area & Hectares & $\%$ Area \\
\hline Eelgrass appeared & 0.58 & 11.00 & 1.17 & 22.31 \\
\hline Eelgrass increased & 0.47 & 8.85 & 0.47 & 8.92 \\
\hline Eelgrass unchanged & 0.40 & 7.62 & 0.29 & 5.54 \\
\hline Eelgrass decreased & 1.39 & 26.38 & 0.93 & 17.77 \\
\hline Eelgrass disappeared & 0.99 & 18.77 & 1.13 & 21.46 \\
\hline Unvegetated in both surveys & 1.42 & 27.38 & 1.26 & 24.00 \\
\hline Total & 5.25 & 100.00 & 5.25 & 100.00 \\
\hline
\end{tabular}

\section{Scituate Harbor}

\section{Bathymetry}

Bathymetric conditions for the 2001 survey (Figure 10) indicated considerable shoaling in the anchorage area. The bathymetric grid difference map for 2001/2003 (Figure 11) illustrates changes in depth as a result of dredging. The difference between these two surveys represents approximately $115,000 \mathrm{~m}^{3}$ of material removed from within the surveyed area alone. Relatively little change in bathymetry occurred between the 2003 and 2004 surveys (maps not shown).

Based on pre- and post-dredging bathymetric change, the channel and anchorage survey areas were further divided into dredged (deepened within project boundaries) and undredged (all other areas) treatment regions for analysis of eelgrass change (Figure 11). Within the anchorage, the dredged and undredged portions were approximately equal in size, 5.5 and 5.4 ha, respectively. Within the channel, the dredged area was approximately $0.8 \mathrm{ha}$, and the adjacent undredged survey area was 2.9 ha. 


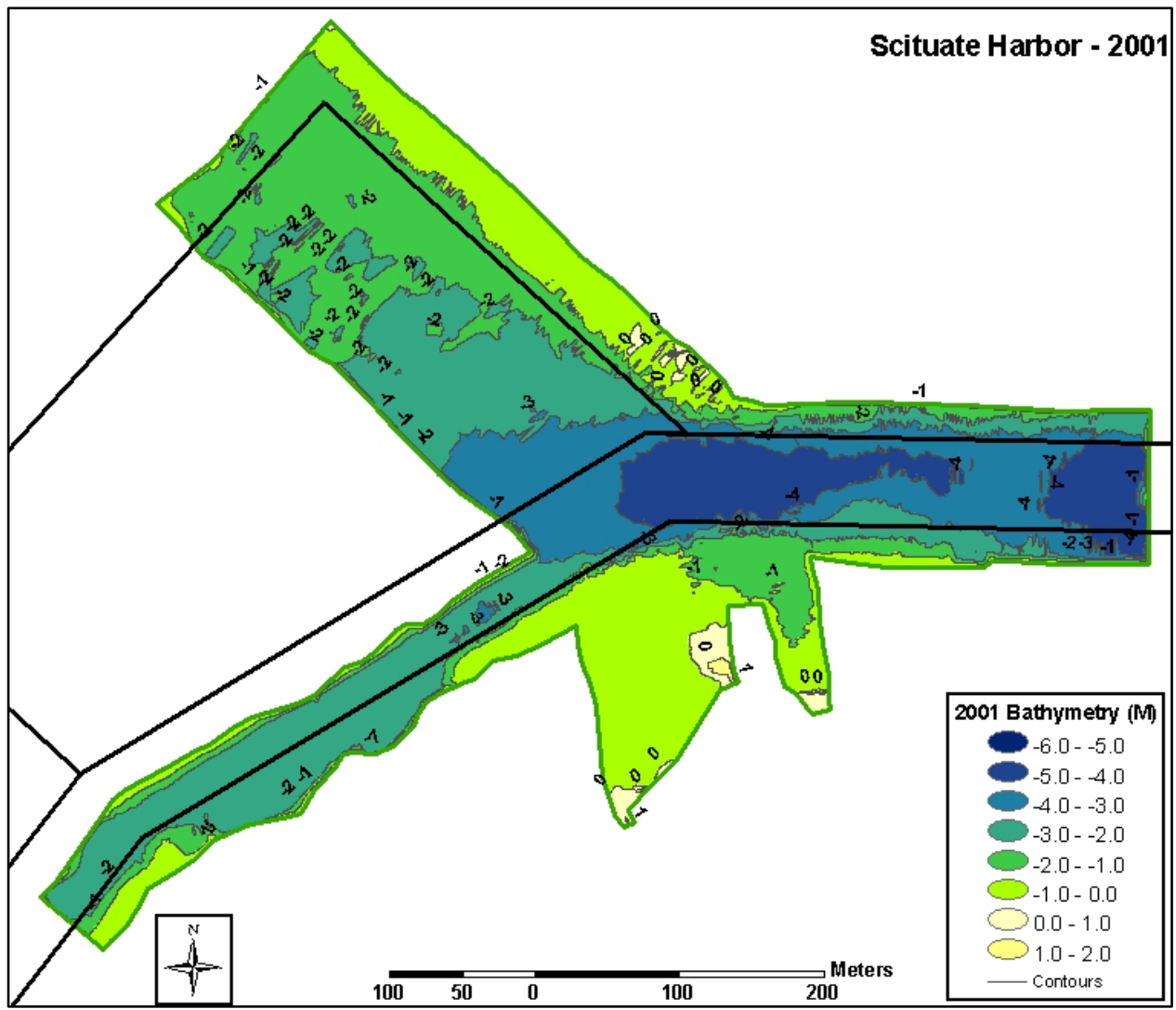

Figure 10. Bathymetric map of Scituate Harbor, 2001

\section{Use of silt curtains}

Deployment of silt curtains proved to be a complicating factor in the Scituate study. Accurate records were not kept of the exact locations of the curtains on specific dates, or of the performance of the silt curtains throughout the dredging period. Although the agencies recommended the use of silt curtains in an effort to minimize indirect effects to eelgrass resources due to increased turbidity and siltation, the design of the curtains installed by the contractor may have been inadequate for the hydrodynamic conditions prevalent in the study area. High tidal flow resulted in breakage of anchor lines and rupture of the seams of the curtains. ${ }^{1}$ It was therefore not possible to evaluate the efficacy of silt curtains in this study.

\footnotetext{
${ }^{1}$ Personal communication, 2005, Mr. Todd Randall, U.S. Army Engineer District, New England.
} 


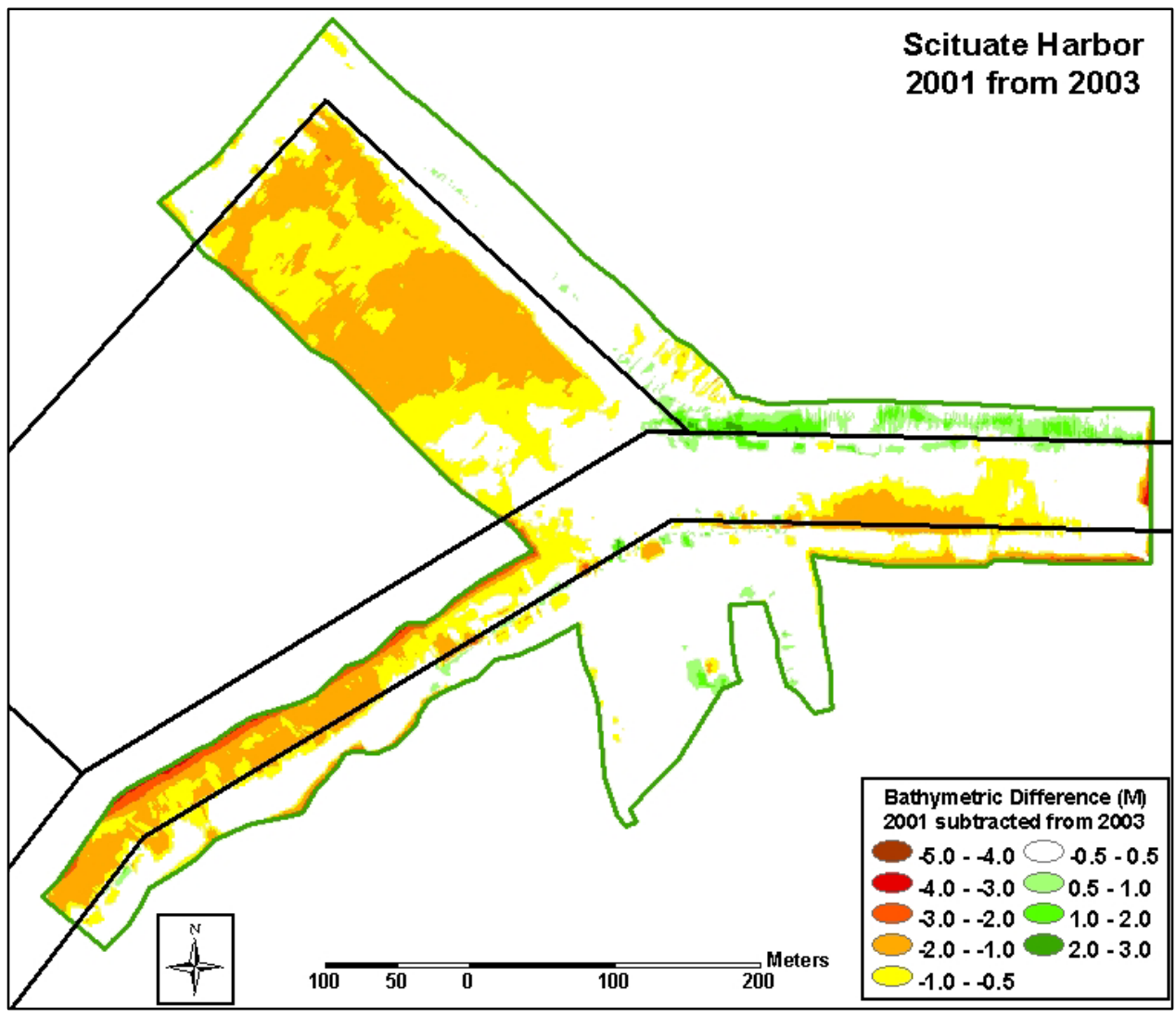

Figure 11. Bathymetric grid difference between 2001 and 2003 (pre- and postdredging): note that negative numbers indicate increased depth while positive numbers indicate decreased depth

\section{Seagrass depth distribution}

Mean eelgrass coverage by depth increments showed greatest differences between pre-dredge and post-dredge surveys (Figure 12). Within the dredged portion of the anchorage, the only concentration of eelgrass (in the shallows, less than $-1.5 \mathrm{~m}$ MLLW) was removed. Within the undredged portion of the anchorage, a large decline was evident at all depths between 2001 and 2003 followed by modest increases at all depths between 2003 and 2004. The dredged portion of the channel area shows what appears to be a sizeable gain in eelgrass at a depth of $-3.0 \mathrm{~m}$ MLLW. This is actually an artifact because the amount of eelgrass area in this depth stratum was reduced from 30 percent of the total area to less than 5 percent by the dredging activity. Within the undredged portion of the channel, differences between surveys for the pre- and post-dredging periods were minimal except for a slight decline in coverage between 2.75 and $3.35 \mathrm{~m}$ below MLLW. 

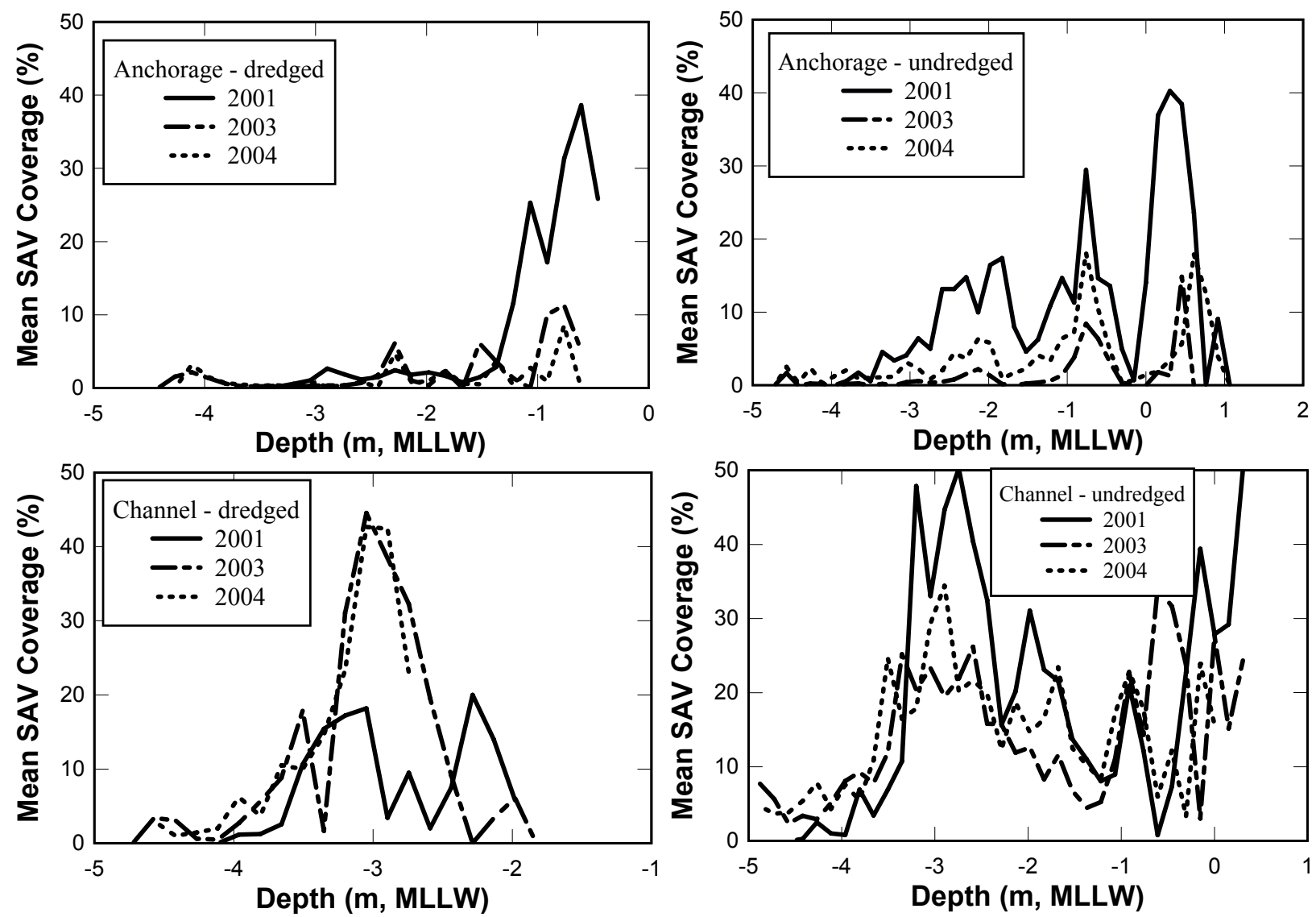

Figure 12. Mean eelgrass coverage by $0.15-\mathrm{m}$ depth increment in Scituate Harbor for dredged and undredged anchorage area, and for dredged and undredged channel area

\section{Total vegetated area}

Total vegetated area within each location and treatment was computed from the gridded coverage data by survey year (Table 3). Overall, the entire area surveyed showed a 34-percent relative decrease in total vegetated area between 2001 and 2003, and an 8-percent increase from 2003 to 2004. Within the anchorage, total vegetated area decreased by 77 percent and 65 percent, in dredged and undredged areas, respectively, between pre- and first year post-dredging surveys. Between first and second year post-dredging surveys, substantial recovery ( +49 percent) occurred in the undredged anchorage, while negligible change occurred within the dredged anchorage. The dredged portion of the channel showed a 29-percent decrease in vegetated area between pre- and first-year postdredging surveys, while the undredged channel exhibited a 30-percent increase during the same interval. Between first and second year post-dredging surveys, little change was evident in either of the two channel areas. 


\begin{tabular}{|c|c|c|c|c|c|}
\hline \multicolumn{6}{|c|}{$\begin{array}{l}\text { Table } 3 \\
\text { Summary of Total Vegetated Area (ha) in Scituate Harbor by } \\
\text { Location, Treatment, and Year }\end{array}$} \\
\hline \multirow[b]{2}{*}{ Location } & \multirow[b]{2}{*}{ Treatment } & \multicolumn{3}{|c|}{$\begin{array}{c}\text { Total Vegetated Area (ha) } \\
\text { by Year }\end{array}$} & \multirow[b]{2}{*}{ Total Area (ha } \\
\hline & & 2001 & 2003 & 2004 & \\
\hline \multirow[t]{2}{*}{ Anchorage } & Dredged & 0.61 & 0.14 & 0.15 & $\bar{~} 5.52$ \\
\hline & Undredged & 1.42 & 0.49 & 0.71 & 5.37 \\
\hline \multirow[t]{2}{*}{\begin{tabular}{|l|} 
Channel \\
\end{tabular}} & Dredged & 0.17 & 0.12 & 0.13 & 0.81 \\
\hline & Undredged & 1.10 & 1.43 & 1.36 & 2.95 \\
\hline All & All & 3.30 & 2.18 & 2.35 & 14.65 \\
\hline
\end{tabular}

\section{Statistical distribution of coverage}

The statistical distribution of gridded coverage values (Figure 13, Table 4) reveals how eelgrass coverage changed over time within these areas. Although dredged areas in the channel and anchorage both exhibited a large overall decline in eelgrass cover between pre- and first year post-dredging surveys, there were slight differences in the responses of the various eelgrass cover classes (Table 4). The largest proportion of eelgrass in both areas was classified as sparse (more than 5-25 percent cover). While the proportion of sparse eelgrass declined in the dredged anchorage area, there was little change in the proportion of sparse eelgrass within the dredged channel area. There was little evidence of eelgrass recovery (i.e. no increase) in either of these two areas between first and second year post-dredging surveys. A similar large decline in all coverage levels after dredging occurred in the undredged anchorage region, followed by a modest recovery between 2003 and 2004. The undredged portion of the channel showed an increase in sparse eelgrass following dredging, in conjunction with a slight decrease in dense eelgrass; little change was evident between the 2003 and 2004 surveys.

\section{Mapping}

Maps of spatial coverage (Figure 14) also illustrate significant redistribution over time. Consistent with the results of the non-spatial analyses presented previously, large overall declines in eelgrass area and cover were apparent between pre-dredging and first year post-dredging surveys. This decline was greatest in the undredged anchorage region. A slight overall increase in coverage was evident between first and second year post-dredging surveys. Comparing the gridded coverages and assigning results to the change categories described in Data Analysis illustrates specific locations of change (Figures 15 and 16). Large areas of "disappearance" were evident in the anchorage region, both in dredged and undredged sections, between pre- and first year post-dredging surveys (Figure 15). During the same period, the channel area showed some redistribution but no comparable decrease. There is some evidence of recovery in most areas between first and second year post-dredging surveys (Figure 16). 

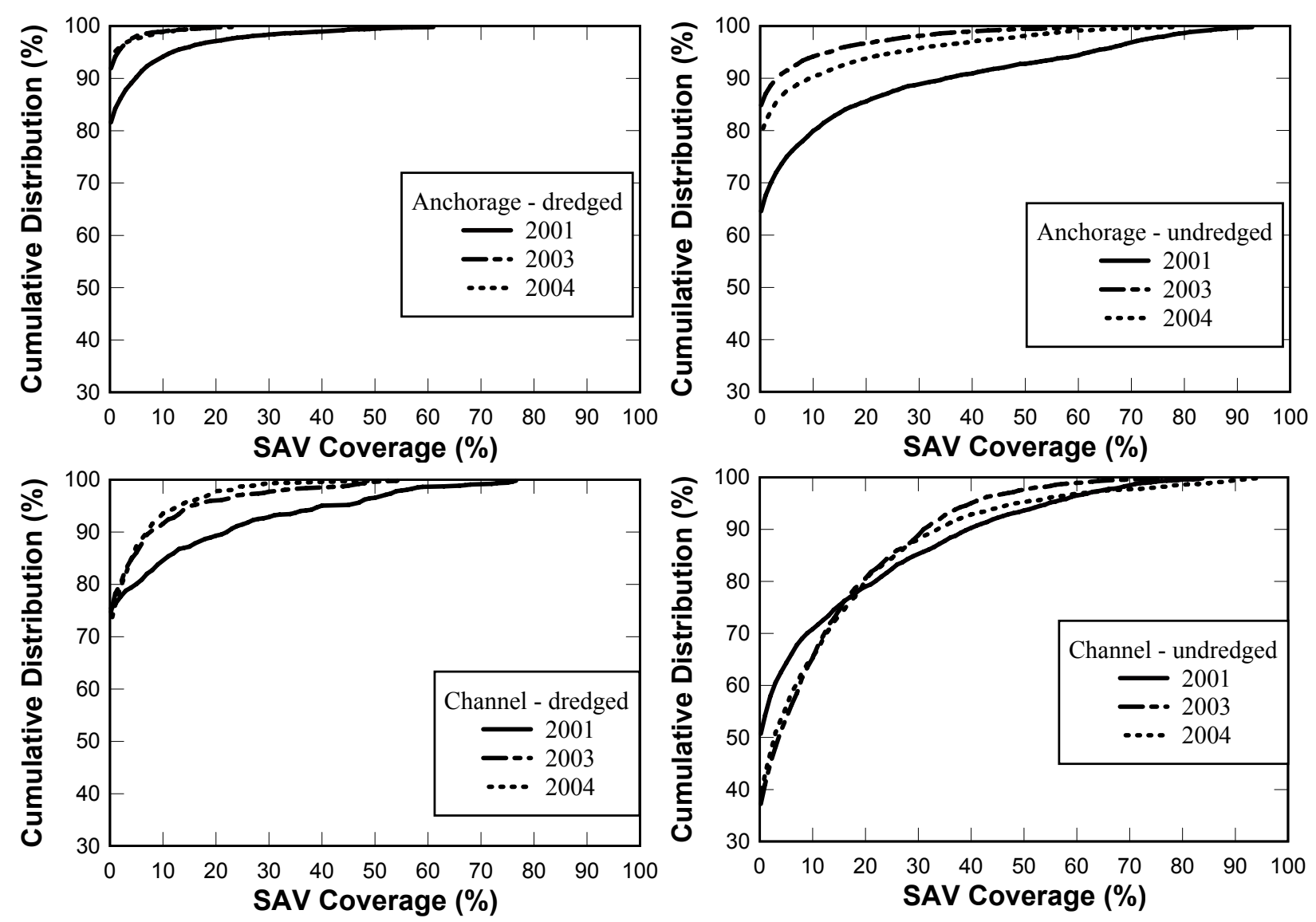

Figure 13. Distribution of gridded eelgrass coverage in Scituate by region

\begin{tabular}{|l|l|l|l||}
\hline Table 4 \\
Classes of Gridded Eelgrass Coverage Data by Location, \\
Treatment, and Year
\end{tabular}




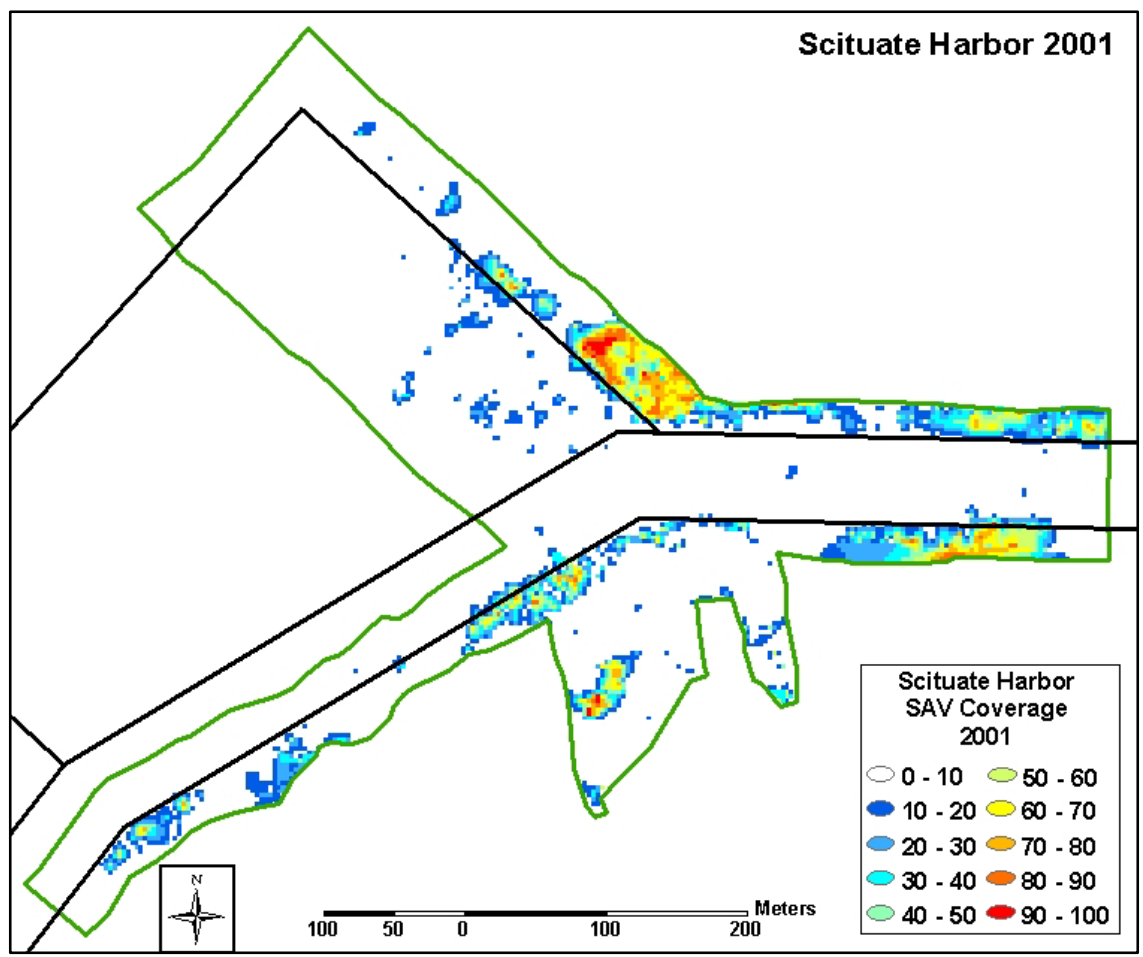

a) 2001

Figure 14. Eelgrass coverage map of Scituate Harbor: a) 2001, b) 2003, c) 2004

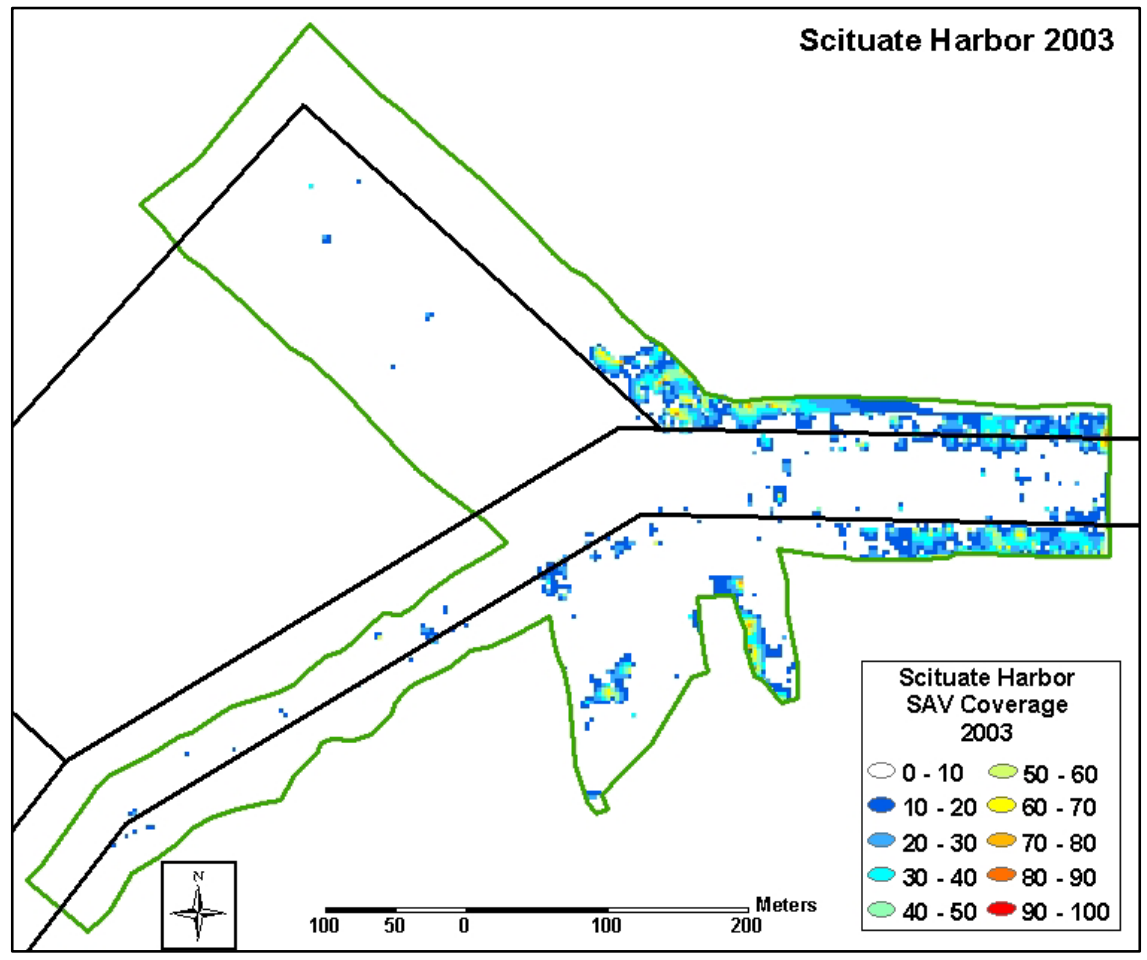

b) 2003 


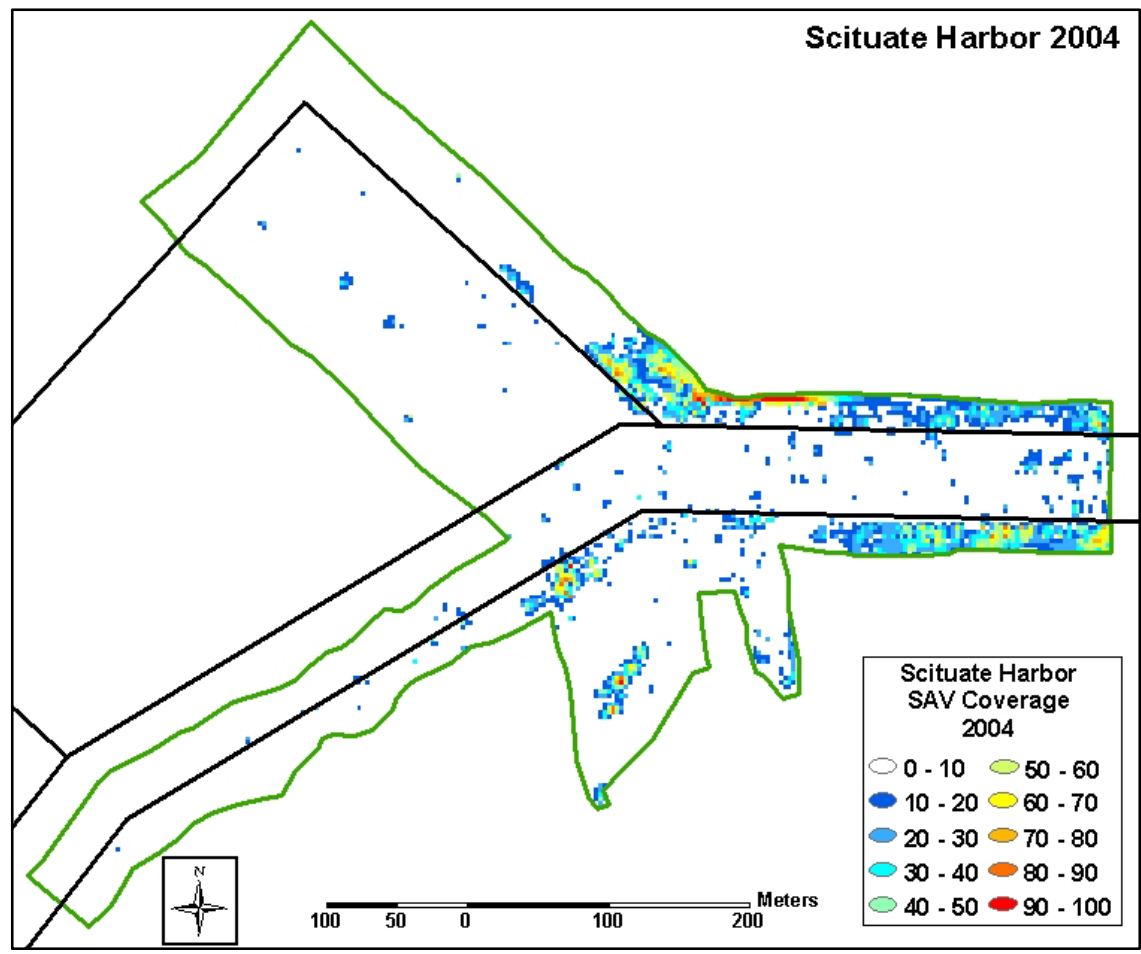

c) 2004

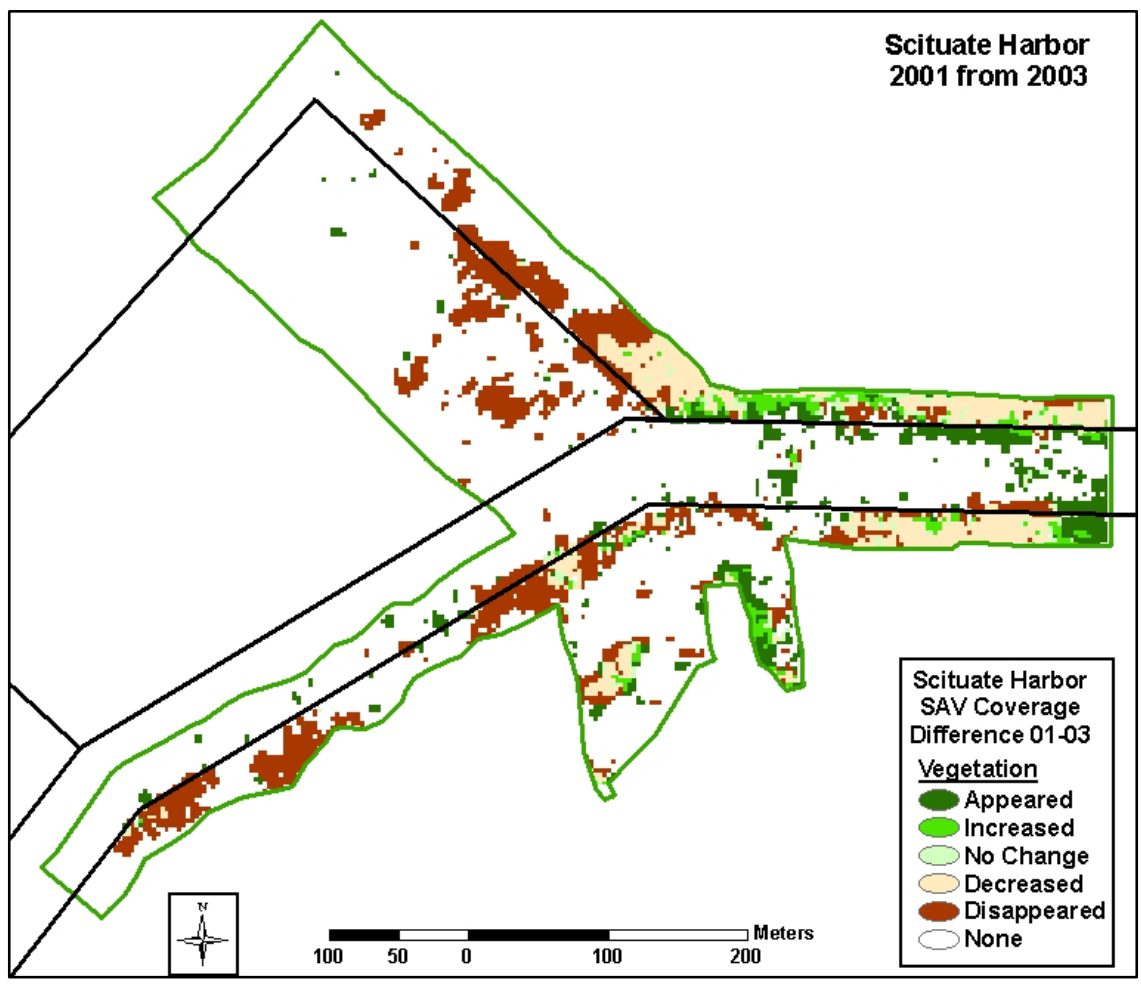

Figure 15. Map of eelgrass coverage grid difference for years 2001 and 2003 for Scituate Harbor 


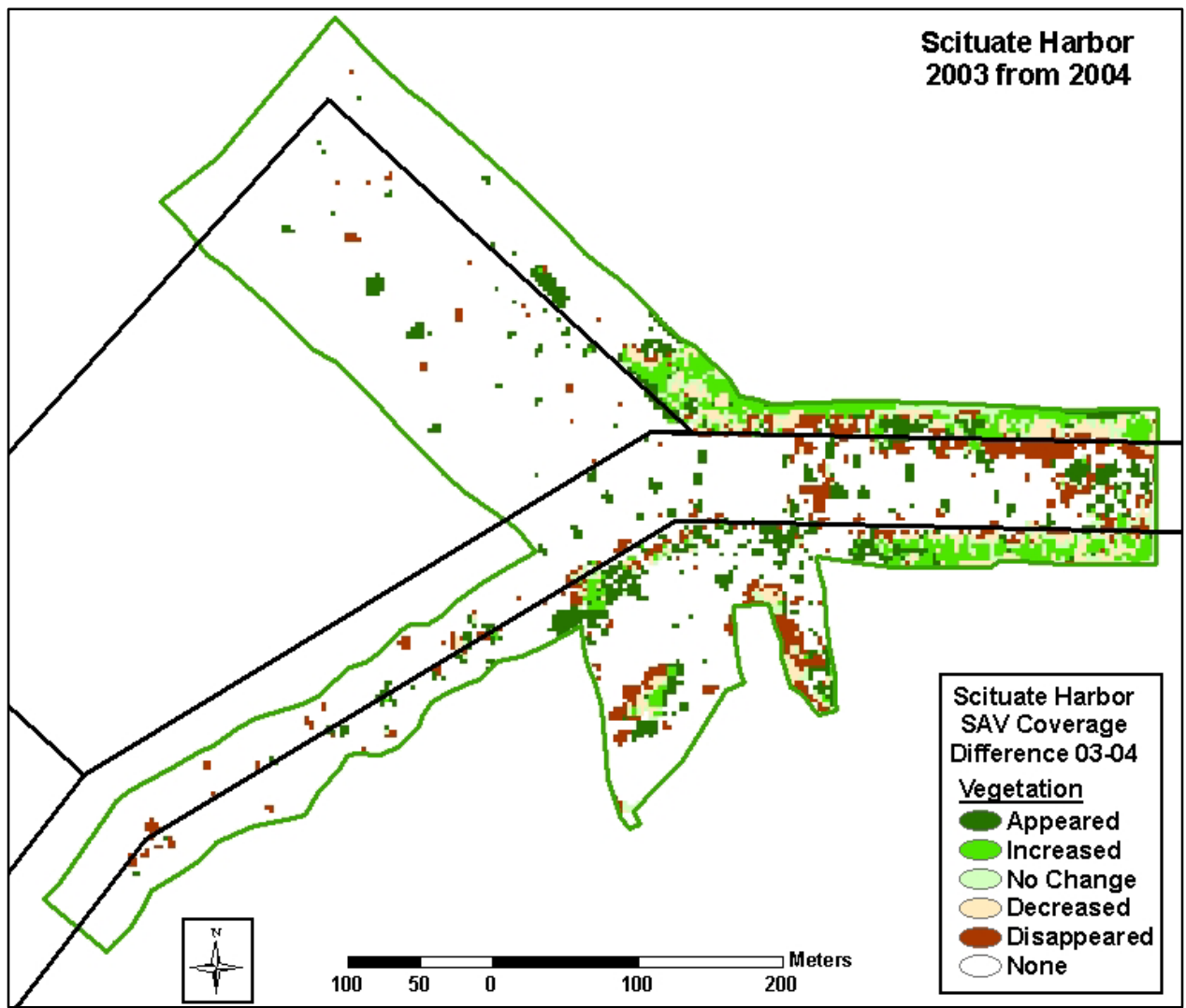

Figure 16. Map of eelgrass coverage grid difference for years 2003 and 2004 for Scituate Harbor

\section{Map analysis}

The areas, and corresponding percentages, in different coverage change categories were tabulated by location and treatment (Tables 5 and 6). Comparing the pre- and first year post-dredging surveys, the greatest relative losses occurred in undredged anchorage (-87 percent) and dredged anchorage (-80 percent) regions, with lesser losses in the dredged channel region ( -65 percent), and a slight relative gain in the undredged channel $(+5$ percent $)$. Between the first and second year post-dredging surveys, the dredged areas showed no recovery 0 percent net change for the dredged anchorage and a further relative change of 17 percent within the dredged channel. During the same period, the undredged anchorage showed appreciable recovery with a net increase of 0.31 ha, which corresponds to an 80-percent relative increase (owing to the small amount of vegetation present there in 2003). The undredged channel showed a small relative increase ( +6 percent) during this final period. Note that these areas and percentages are larger than those for total vegetated area (Table 3) described above, because these also account for the area in increase and decline, not just presence. 


\begin{tabular}{|c|c|c|c|c|c|}
\hline \multicolumn{6}{|c|}{$\begin{array}{l}\text { Table } 5 \\
\text { Eelgrass Coverage Change Analysis for Dredged Portions of } \\
\text { Scituate Harbor }\end{array}$} \\
\hline \multirow[b]{3}{*}{ Region } & \multirow{3}{*}{$\begin{array}{l}\text { Vegetation Change } \\
\text { Category }\end{array}$} & \multicolumn{4}{|c|}{ Area by Vegetation Change Category } \\
\hline & & \multicolumn{2}{|c|}{$\begin{array}{c}\text { Pre/Post-Dredging Period } \\
(2003-2001)\end{array}$} & \multicolumn{2}{|c|}{$\begin{array}{c}\text { Post-Dredging Period } \\
(2004-2003)\end{array}$} \\
\hline & & Hectares & $\%$ Area & Hectares & $\%$ Area \\
\hline \multirow[t]{7}{*}{ Anchorage } & Eelgrass appeared & 0.09 & 1.61 & 0.12 & 2.13 \\
\hline & Eelgrass increased & $<0.01$ & 0.15 & 0.01 & 0.22 \\
\hline & Eelgrass unchanged & 0.02 & 0.30 & 0.01 & 0.22 \\
\hline & Eelgrass decreased & 0.02 & 0.44 & 0.01 & 0.22 \\
\hline & Eelgrass disappeared & 0.56 & 10.12 & 0.12 & 1.91 \\
\hline & $\begin{array}{l}\text { Unvegetated for both } \\
\text { surveys }\end{array}$ & 4.82 & 87.38 & 5.26 & 95.30 \\
\hline & Anchorage total & 5.52 & 100.00 & 5.52 & 100.00 \\
\hline \multirow[t]{7}{*}{ Channel } & Eelgrass appeared & 0.06 & 7.54 & 0.08 & 10.06 \\
\hline & Eelgrass increased & $<0.01$ & 1.00 & $<0.01$ & 1.00 \\
\hline & Eelgrass unchanged & $<0.01$ & 1.00 & 0.02 & 2.00 \\
\hline & Eelgrass decreased & 0.05 & 6.03 & 0.02 & 2.51 \\
\hline & Eelgrass disappeared & 0.12 & 13.06 & 0.08 & 9.55 \\
\hline & $\begin{array}{l}\text { Unvegetated for both } \\
\text { surveys }\end{array}$ & 0.58 & 71.37 & 0.60 & 74.88 \\
\hline & Channel total & 0.81 & 100.00 & 0.81 & 100.00 \\
\hline
\end{tabular}

\section{Table 6}

Eelgrass Coverage Change Analysis for Undredged Areas of Scituate Harbor

\begin{tabular}{|c|c|c|c|c|c|}
\hline \multirow[b]{3}{*}{ Region } & \multirow{3}{*}{$\begin{array}{l}\text { Vegetation Change } \\
\text { Category }\end{array}$} & \multicolumn{4}{|c|}{ Area by Vegetation Change Category } \\
\hline & & \multicolumn{2}{|c|}{$\begin{array}{l}\text { Pre/Post-Dredging Period } \\
(2003-2001)\end{array}$} & \multicolumn{2}{|c|}{$\begin{array}{c}\text { Post-Dredging Period } \\
(2004-2003)\end{array}$} \\
\hline & & Hectares & $\%$ Area & Hectares & $\%$ Area \\
\hline \multirow[t]{7}{*}{ Anchorage } & Eelgrass appeared & 0.10 & 1.89 & 0.38 & 7.01 \\
\hline & Eelgrass increased & 0.02 & 0.45 & 0.17 & 3.17 \\
\hline & Eelgrass unchanged & 0.04 & 0.83 & 0.08 & 1.51 \\
\hline & Eelgrass decreased & 0.32 & 5.96 & 0.08 & 1.58 \\
\hline & Eelgrass disappeared & 1.03 & 19.16 & 0.16 & 2.94 \\
\hline & $\begin{array}{l}\text { Unvegetated for both } \\
\text { surveys }\end{array}$ & 3.85 & 71.71 & 4.50 & 83.79 \\
\hline & Anchorage total & 5.37 & 100.00 & 5.37 & 100.00 \\
\hline \multirow[t]{7}{*}{ Channel } & Eelgrass appeared & 0.55 & 18.84 & 0.40 & 13.44 \\
\hline & Eelgrass increased & 0.22 & 7.43 & 0.43 & 14.67 \\
\hline & Eelgrass unchanged & 0.17 & 5.64 & 0.27 & 9.05 \\
\hline & Eelgrass decreased & 0.49 & 16.64 & 0.27 & 8.91 \\
\hline & Eelgrass disappeared & 0.22 & 7.57 & 0.47 & 16.06 \\
\hline & $\begin{array}{l}\text { Unvegetated for both } \\
\text { surveys }\end{array}$ & 1.29 & 43.88 & 1.11 & 37.87 \\
\hline & Channel total & 2.95 & 100.00 & 2.95 & 100.00 \\
\hline
\end{tabular}




\begin{tabular}{|c|c|c|c|c|c|}
\hline \multicolumn{6}{|c|}{$\begin{array}{l}\text { Table } 7 \\
\text { Summary of Net and Relative Change in SAV Coverage for Scituate } \\
\text { Harbor by Location, Treatment, and Paired Surveys }\end{array}$} \\
\hline \multirow[b]{2}{*}{ Location } & \multirow[b]{2}{*}{ Treatment } & \multicolumn{2}{|c|}{$2001 / 2003$} & \multicolumn{2}{|c|}{$2003 / 2004$} \\
\hline & & \begin{tabular}{|l|} 
Net Change, \\
ha (\%) \\
\end{tabular} & $\begin{array}{l}\text { Relative } \\
\text { Change (\%) }\end{array}$ & $\begin{array}{l}\text { Net Change, } \\
\text { ha (\%) }\end{array}$ & \begin{tabular}{|l|} 
Relative \\
Change (\%)
\end{tabular} \\
\hline \multirow[t]{2}{*}{ Anchorage } & Dredged & $-0.49(-9)$ & -80 & $0(0)$ & 0 \\
\hline & Undredged & $-1.23(-23)$ & -87 & $+0.31(+6)$ & +80 \\
\hline \multirow[t]{2}{*}{ Channel } & Dredged & $-0.11(-14)$ & -65 & $-0.02(-2)$ & -17 \\
\hline & Undredged & $+0.06(+2)$ & +5 & $+0.09(+3)$ & +6 \\
\hline
\end{tabular}




\section{Discussion}

Wood Island Harbor contains an established population of eelgrass unaffected by recent dredging activity. Here the eelgrass exhibited a steady decline over the course of three surveys. Total vegetated area decreased 13 percent between 2001 and 2003, and then remained relatively stable between 2003 and 2004. However, the redistribution of eelgrass within the survey area was more complex than indicated by consideration of total vegetated area alone. Based on an analysis of net increase/decrease (Table 2), 40 percent of the vegetated area present in 2001 decreased or disappeared by 2003, and 15 percent of the vegetated area present in 2003 decreased or disappeared by 2004 . Associated with this decline was significant horizontal (spatial) and vertical (depth) redistribution. Dense established beds in the deeper ends of the channel declined and sparse beds in the shallow mid-section appeared during the last survey.

The observed interannual spatial redistribution of eelgrass within Wood Island Harbor is evidence of the variability inherent in seagrass meadows. Declines or losses in seagrass coverage in some parts of the mapped area were accompanied by simultaneous increases in seagrass coverage and/or colonization of previously unvegetated areas. Natural interannual variability in eelgrass biomass is seldom considered due to the limited duration of most studies, yet can be substantial (Nelson 1997). This presents a challenge to studies attempting to distinguish the impact of a single event, such as dredging, against a background of variability due to other sources.

Over the same period, eelgrass at Scituate Harbor exhibited an overall relative decline of 34 percent in total vegetated area between pre- and postdredging surveys, followed by an 8-percent relative increase between first and second year post-dredging surveys. At first glance, eelgrass declines at Scituate between 2001 and 2003 are more than twice that of Wood Island Harbor. However, these values cannot be directly compared, since the estimates include both direct impacts associated with dredging operations as well as potential indirect impacts in adjacent undredged areas.

Obviously, eelgrass declines in the dredged areas can be attributed to physical removal of the vegetation along with the sediments. The dredged anchorage area exhibited a large initial decline (loss of 77 percent total vegetated area, with 80 percent of area in net decline) between pre- and post-dredging surveys. In the subsequent survey in 2004, there was little evidence of recovery in the dredged anchorage, since it remained effectively unvegetated. In the 
entrance channel, the dredged area exhibited a smaller relative decline (loss of 29 percent total vegetated area, with 65 percent of area in net decline) between the pre-dredging and first post-dredging surveys, with no evidence of recovery during the post-dredging period.

Within the undredged anchorage area, the relative decline in eelgrass between pre- and post-dredging surveys was similar to that seen within the dredged portion - loss of 65 percent of vegetated area with 87 percent of the area in a net decline. In the period between first and second year post-dredging surveys, a substantial recovery was evident -45 -percent relative increase in vegetated area with 80 percent of the area in net increase. It should be noted that "recovered" levels in 2004 were still well below those present in 2001. Within the undredged portion of the entrance channel, little change was evident among all three surveys.

Attributing a cause to the decline and subsequent recovery of eelgrass in the undredged anchorage portion of Scituate Harbor is more complex. The large initial decline was considerably greater than the decline observed at undredged Wood Island Harbor during the same period. This suggests a possible indirect impact of dredging in the anchorage area, perhaps resulting from temporary increases in turbidity and/or sedimentation. Unfortunately, there were no direct measurements of light attenuation, turbidity, or sedimentation during dredging operations. The lack of change in eelgrass acreage in the undredged entrance channel area suggests that there were no indirect impacts associated with dredging in this area. One possible explanation involves differences in dredged material composition in these two areas. In the entrance channel, dredged materials were primarily coarse sands and small cobble, which were likely to settle rapidly and contribute little to increased water column turbidity. On the other hand, sediments in the anchorage basin were predominantly silt, and were more likely to become resuspended in the water column, resulting in increased turbidity.

The relatively large increase in vegetated acreage within the undredged anchorage area between 2003 and 2004 indicates that indirect dredging impacts, if present, are probably short-term, and that eelgrass populations are capable of making substantial recovery within two growing seasons. This recovery occurred in spite of apparent regional trends of declining eelgrass coverage at a site unaffected by dredging.

The lack of recovery within the dredged anchorage area suggests some mechanism is effectively limiting eelgrass recolonization. The inner anchorage area was dredged to a relatively uniform depth of $-3.0 \mathrm{~m}$ MLLW in half the area and to $-2.4 \mathrm{~m}$ MLLW in the other half. Examination of the eelgrass depth distribution profiles (Figure 12) for the anchorage area prior to dredging reveals that virtually all eelgrass was within the shallow area (more than $-1.5 \mathrm{~m}$ MLLW) that was dredged and almost none (less than 5 percent) at project depths. Therefore, at project depths, light availability is likely to be the major limiting factor affecting eelgrass recolonization. Physical disturbance of the bottom sediments due to boat moorings, and shading by moored vessels could also be factors affecting eelgrass recolonization within the anchorage area (Walker et al. 1989; Hastings et al. 1995). 


\section{Conclusions}

Conclusions of this study are as follows:

a. Direct impacts within dredged areas were readily measured by temporal changes in spatial distribution of eelgrass.

b. Normal inter-annual variability observed at an undisturbed site in the absence of dredging was substantial; studies designed to detect dredging impacts should take this into consideration.

c. Indirect impacts in areas where the dredged sediments are coarse may be minimal.

d. Indirect impacts are more likely to be present in areas where the dredged sediments are fine-grained and easily resuspended.

e. Evidence of substantial recolonization and recovery processes was present at Scituate Harbor within 1-2 growing seasons.

$f$. Due to problems encountered in the deployment and maintenance of silt curtains in Scituate Harbor, it could not be determined whether they were an effective means of reducing indirect impacts to eelgrass resources. 


\section{References}

Abal, E., Loneragan, N., Bowen, P., Perry, C., Udy, J. and Dennison,W. (1994). "Biological and morphological responses of the seagrass Zostera capricorni Aschers. to light intensity," Journal of Experimental Marine Biology and Ecology 178, 113-129.

Baldwin, J. R., and Lovvorn, J. R. (1994). "Habitats and tidal accessibility of the marine foods of dabbling ducks and brant in Boundary Bay, British Columbia," Marine Biology 120, 627-638.

Bulthuis, D. A. (1983). "Effects of in situ light reduction on density and growth of the seagrass Heterozostera tasmanica (Martens ex Aschers.) den Hartog in Western Port, Victoria, Australia," Journal of Experimental Marine Biology and Ecology 67, 91-103.

Dennison, W. (1987). "Effects of light on seagrass photosynthesis, growth, and depth distribution," Aquatic Botany 27, 15-26.

Fonseca, M., Fisher, J., Zieman, J., and Thayer, G. (1982). "Influence of the seagrass, Zostera marina L. on current flow," Estuarine, Coastal, and Shelf Science 15, 351-364.

Ganter, B. (2000). "Seagrass (Zostera spp.) as food for brent geese (Branta bernicla): an overview," Helgoland Marine Research 54, 63-70.

Hastings, K., Hesp, P. and Kendrick, G. (1995). "Seagrass loss associated with boat moorings at Rottnest Island, Western Australia," Ocean and Coast Management 26, 225-246.

High, C., Paivo, M. and Demos, C. (2001). "Proposed maintenance dredging of Scituate Harbor: Environmental assessment," U.S. Army Engineer District, New England, Concord, MA.

Hughes, J., Deegan, L., Wyda, J., Weaver, M. and Wright, A. (2002). "The effects of eelgrass habitat loss on estuarine fish communities of southern New England," Estuaries 25, 235-249.

Kenworthy, W., and Fonseca, M. (1996). "Light requirements of seagrasses Halodule wrightii and Syringodium filiforme derived from the relationship 
between diffuse light attenuation and maximum depth penetration," Estuaries $19,740-750$.

Long, B., Dennis, D., Skewes, T. and Poiner, I. (1996). "Detecting an environmental impact of dredging on seagrass beds with a BACIR sampling design," Aquatic Botany 53, 235-243.

Nelson, T. (1997). "Interannual variance in a subtidal eelgrass community," Aquatic Botany 56, 245-252.

Onuf, C. (1994). "Seagrasses, dredging and light in Laguna Madre," Estuarine, Coastal and Shelf Science 39, 75-91.

Quammen, M., and Onuf, C. (1993). "Laguna Madre: Seagrass changes continue decades after salinity reduction," Estuaries 16, 302-310.

Reynolds, W., and Casterlin, M. (1985). "Vagile macrofauna and hydrographic environment of the Saco River estuary and the adjacent waters of the Gulf of Maine," Hydrobiologia 128, 207-215.

Sabol, B., McCarthy, E., and Rocha, K. (1997). "Hydroacoustic basis for detection and characterization of eelgrass (Zostera marina)." Proceedings of the 4th Conference on Remote Sensing of Marine Environments, I-679-693.

Sabol, B., Melton, E., Chamberlain, R., Doering, P. and Haunert, K. (2002). "Evaluation of a digital echo sounder for detection of submersed aquatic vegetation," Estuaries 25, 133-141.

Short, F. and Wyllie-Echeverria, S. (1996). "Natural and human-induced disturbance of seagrasses," Environmental Conservation 23, 17-27.

Sibson, R. (1981). "A brief description of natural neighbor interpolation." Interpreting multivariate data. V. Barnett, ed., John Wiley and Sons, Inc., New York, 22-36.

Thayer, G., Kenworthy,W., and Fonseca, M. (1984). "The ecology of eelgrass meadows of the Atlantic Coast: A community profile," U.S. Fish and Wildlife Service Report No. FWS OBS-84/02.

U.S. Army Corps of Engineers. (2002). "Hydrographic surveying," Engineer Manual 1110-2-1003, Department of the Army, Washington, DC.

Walker, D., Lukatelich, R., Bastyan, G., and McComb, A. (1989). "The effect of boat moorings on seagrass beds near Perth, Western Australia," Aquatic Botany 36, 69-77.

Zieman, J., and Zieman, R. (1989). "The ecology of the seagrass meadows of the west coast of Florida: A community profile," U.S. Fish and Wildlife Service Biological Report 85(7.25). 


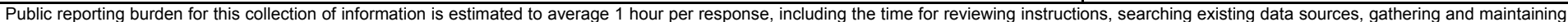

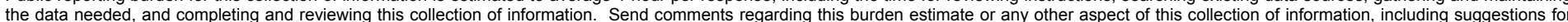

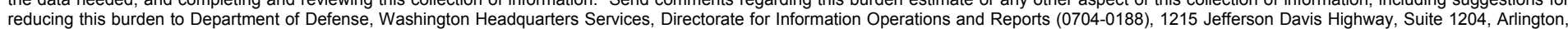

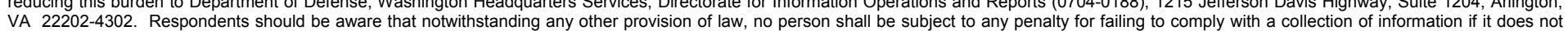
display a currently valid OMB control number. PLEASE DO NOT RETURN YOUR FORM TO THE ABOVE ADDRESS.

\begin{tabular}{l|c}
$\begin{array}{l}\text { 1. REPORT DATE (DD-MM-YYYY) } \\
\text { July } 2005\end{array}$ & $\begin{array}{c}\text { 2. REPORT TYPE } \\
\text { Final report }\end{array}$ \\
\hline
\end{tabular}

\section{TITLE AND SUBTITLE}

Dredging Effects on Eelgrass (Zostera marina) Distribution

in a New England Small Boat Harbor

\section{DATES COVERED (From - To)}

\section{5a. CONTRACT NUMBER}

5b. GRANT NUMBER

5c. PROGRAM ELEMENT NUMBER

\section{AUTHOR(S)}

\section{5d. PROJECT NUMBER}

Bruce Sabol, Deborah Shafer, Elizabeth Lord

5e. TASK NUMBER

\section{5f. WORK UNIT NUMBER}

\section{PERFORMING ORGANIZATION NAME(S) AND ADDRESS(ES)}

8. PERFORMING ORGANIZATION REPORT
NUMBER

Environmental Laboratory

U.S. Army Engineer Research and Development Center

ERDC/EL TR-05-8

3909 Halls Ferry Road, Vicksburg, MS 39180-6199

\section{SPONSORING / MONITORING AGENCY NAME(S) AND ADDRESS(ES)}

10. SPONSOR/MONITOR'S ACRONYM(S)

U.S. Army Engineer District, New England

Concord, MA 01742-2751

11. SPONSOR/MONITOR'S REPORT NUMBER(S)

\section{DISTRIBUTION / AVAILABILITY STATEMENT}

Approved for public release; distribution is unlimited.

\section{SUPPLEMENTARY NOTES}

\section{ABSTRACT}

While speculation on effects of dredging on seagrass beds is plentiful, actual empirical data documenting these effects are not. In this study, acoustic-based seagrass mapping techniques were used to generate detailed maps of seagrass distribution before and after dredging operations. Eelgrass (Zostera marina) within Scituate Harbor, MA, was monitored during mid-summer in 2001, 2003, and 2004; navigation maintenance dredging of the harbor was performed during fall 2002. Similar surveys were also performed during the same timeframe at an undredged harbor near Wood Island, ME. Two types of potential impacts were examined. Direct impacts involved physical removal of vegetation along with the dredged sediments. Indirect impacts in adjacent undredged areas may occur as a result of increased turbidity and/or siltation associated with dredging activities. Using hydroacoustic techniques, the authors were able to easily map and quantify direct impacts to eelgrass resources. Assessment of indirect impacts, however, was more complex. In the first postdredging survey, a substantial reduction in coverage occurred in adjoining undredged areas, suggesting possible indirect impacts. This was followed by a modest recovery between the first and second post-dredging years. However, monitoring of other undredged sites within the region showed natural year-to-year variations in eelgrass coverage to be almost as large as those occurring at the dredged site. Results emphasize the need for long-term data to discern any potential effects of dredging on seagrass dynamics as opposed to a host of other factors contributing to high variability in measured parameters.

\section{SUBJECT TERMS}

Dredging impacts

Seagrass

Hydroacoustic mapping

16. SECURITY CLASSIFICATION OF:

\section{a. REPORT}

UNCLASSIFIED

b. ABSTRACT
UNCLASSIFIED

c. THIS PAGE

UNCLASSIFIED

\begin{tabular}{l|c|}
$\begin{array}{l}\text { 17. LIMITATION } \\
\text { OF ABSTRACT }\end{array}$ & $\begin{array}{c}\text { 18. NUMBER } \\
\text { OF PAGES }\end{array}$ \\
\cline { 2 - 2 } & 40
\end{tabular}

19a. NAME OF RESPONSIBLE PERSON

19b. TELEPHONE NUMBER (include area code) 